\title{
Holocene surface-rupturing earthquakes on the Dinaric Fault System, western Slovenia
}

\author{
Christoph Grützner ${ }^{1}$, Simone Aschenbrenner ${ }^{2, a}$, Petra Jamšek Rupnik ${ }^{3}$, Klaus Reicherter ${ }^{2}$, Nour Saifelislam ${ }^{2}$, \\ Blaž Vičič $^{4}$, Marko Vrabec ${ }^{5}$, Julian Welte ${ }^{1}$, and Kamil Ustaszewski ${ }^{1}$ \\ ${ }^{1}$ Institute of Geological Sciences, Friedrich-Schiller-Universität Jena, 07749 Jena, Germany \\ ${ }^{2}$ Neotectonics and Natural Hazards Group, RWTH Aachen University, 52056 Aachen, Germany \\ ${ }^{3}$ Geological Survey of Slovenia, Ljubljana, 1000, Slovenia \\ ${ }^{4}$ The Abdus Salam International Centre for Theoretical Physics, Trieste, 34151, Italy \\ ${ }^{5}$ Department of Geology, University of Ljubljana, Ljubljana, 1000, Slovenia \\ anow at: Institute of Geology and Mineralogy, University of Cologne, 50674 Cologne, Germany
}

Correspondence: Christoph Grützner (christoph.gruetzner@uni-jena.de)

Received: 22 January 2021 - Discussion started: 5 February 2021

Revised: 3 August 2021 - Accepted: 6 September 2021 - Published: 4 October 2021

\begin{abstract}
The Dinaric Fault System in western Slovenia, consisting of NW-SE-trending, right-lateral strike-slip faults, accommodates the northward motion of Adria with respect to Eurasia. These active faults show a clear imprint in the morphology, and some of them hosted moderate instrumental earthquakes. However, it is largely unknown if the faults also had strong earthquakes in the late Quaternary. This hampers our understanding of the regional tectonics and the seismic hazard. Geological evidence of coseismic surface ruptures only exists for one historical event, the 1511 Idrija earthquake with a magnitude of $\sim M 6.8$, but the causative fault is still disputed. Here we use geomorphological data, near-surface geophysical surveys, and paleoseismological trenching to study two of these faults: the Predjama Fault and the Idrija Fault. In a paleoseismological trench across the Predjama Fault we found deformation features that may have been caused by an earthquake between $13-0.7 \mathrm{ka}$, very likely not earlier than $8.4 \mathrm{ka}$. At the Idrija Fault, a surface-rupturing earthquake happened around $2.5 \mathrm{ka}$. We show that instrumental and historical seismicity data do not capture the strongest events in this area.
\end{abstract}

\section{Introduction}

This paper is concerned with Holocene surface-rupturing earthquakes on strike-slip faults belonging to the Dinaric Fault System (DFS) in western Slovenia (Fig. 1). Following the established nomenclature in the literature (e.g. Slejko et al., 1989), the faults are named Dinaric faults because they strike parallel to the trend of the Dinarides. However, they must not be confused with the now inactive, SW-vergent Dinaric thrusts. It is well understood that the Dinaric rightlateral faults are active and that they accommodate a share of the relative motion between Adria and Europe (Poljak et al., 2000; Vrabec and Fodor, 2006; Placer et al., 2010; Moulin et al., 2016; Atanackov et al., 2021). However, so far very little is known about their earthquake record. In this rather slowly deforming region, strong but rare earthquakes may dominate the overall seismic moment release. Identifying the strongest earthquake events in the late Quaternary will, therefore, help to better understand the regional active tectonics, shed light on the role of individual faults in the deformation of the crust, and better inform seismic hazard assessments.

Regions of slow continental deformation pose a challenge for active-tectonics studies for several reasons. (i) In lowstrain settings, geodetic techniques that cover only a few decades of monitoring (GPS, InSAR) have to deal with very small amounts of total crustal deformation. This hampers a proper recognition of active structures. (ii) Instrumental seis- 
micity is usually low. Microseismicity studies will, therefore, often not be able to detect active faults. Earthquakes strong enough to compute reliable focal mechanisms, for example by teleseismic body waveform modelling, may not have occurred during the instrumental era. Thus, our understanding of fault mechanisms and seismogenic faults may be limited. (iii) Large earthquakes are rare. Historical catalogues contain felt events but do not necessarily record the strongest possible earthquakes on the local active faults. This is due to the faults' long earthquake recurrence intervals. Also, historical earthquakes can rarely be tied to their causative faults. Earthquakes strong enough to leave their imprints in the landscape must have very large recurrence intervals on slowly moving faults. For the DFS, no long-term recurrence intervals are known. Areas with similar strain rates of a few millimetres per year are known to have recurrence intervals in the order of thousands to tens of thousands of years (e.g. Grützner et al., 2017). Chances are high that their traces were modified or obliterated by erosion and sedimentation before any targeted geoscientific investigations. Notwithstanding all those issues, studying slowly deforming regions and diffuse plate boundaries is important both from the perspectives of active tectonics (e.g. Stein et al., 2009; Landgraf et al., 2017) and seismic hazard (England and Jackson, 2011).

In our study area at the transition zone between the eastern Southern Alps and the Dinarides we are confronted with the above-mentioned problems to varying extents. GPS studies show that there is about $3 \mathrm{~mm} / \mathrm{a}$ of convergence between Adria and Europe at the longitude of the Eastern Alps (D'Agostino et al., 2005, 2008; Weber et al., 2010; Metois et al., 2015), but the station network is too sparse to assess individual faults. Only few reliable moment tensor solutions are available for moderate earthquakes (Anderson and Jackson, 1987; Herak et al., 1995; Bajc et al., 2001; Pondrelli et al., 2002, 2011; Kastelic et al., 2008), and they only occurred on some of the main faults, for example the Ravne Fault earthquakes in 1998 and 2004 (Fig. 1). For historical earthquakes of $M>6$ the causative faults are either unknown or debated (e.g. Tiberi et al., 2018). Similarly, there is a debate about the strongest historical earthquake on record, the 1511 Idrija earthquake, which may have caused surface ruptures on one or two faults (Fitzko et al., 2005; Bavec et al., 2013; Falcucci et al., 2018).

In this paper we present data from paleoseismological trenches dug across two of the large strike-slip faults in western Slovenia: the Idrija and Predjama faults. We show evidence for Holocene surface-rupturing earthquakes on those faults and support our interpretation with geomorphological data, geophysical profiling, and radiocarbon dating. We then discuss the implications of our findings in the light of the regional tectonic setting and seismic hazard.

\section{Geological and tectonic setting}

\subsection{Geological background}

Our study area is located in western Slovenia in the External Dinarides, close to the transition zone between the eastern Southern Alps and the Dinarides (Figs. 1, 2). The area was shaped by the collision of the Adriatic microplate and Europe during the Cenozoic (Schmid et al., 2008; Placer et al., 2010; Ustaszewski et al., 2010; Handy et al., 2015). Shortening in NE-SW direction and the related SW-directed thrusting of Mesozoic carbonates along NW-SE-striking faults lasted from the Cretaceous to the Eocene (Fig. 3). This phase has shaped the large-scale geological picture as we see it today. From the Oligocene to the early Miocene, S-directed transport on E-W-striking faults characterised the phase of south Alpine thrusting. Žibret and Vrabec (2016) used paleostress analyses to distinguish three phases of deformation post-dating the late Eocene NE-SW shortening in western Slovenia: early to middle Miocene back-arc extension in the Pannonian Basin led to NE-SW extension and normal faulting on NW-SE-striking structures. Then, a short pulse of late Miocene E-W contraction led to a left-lateral reactivation of the NW-SE-striking faults and N-S extension. Since the Pliocene, $\mathrm{N}-\mathrm{S}$ shortening is taken up by right-lateral motion on a NW-SE-trending strike-slip fault system known as the Dinaric Fault System (e.g. Poljak et al., 2000; Vrabec and Fodor, 2006; Placer et al., 2010; Moulin et al., 2016; Atanackov et al., 2021; Figs. 1-3). This phase lasts until today and is corroborated by seismological data (e.g. Herak et al., 1995; Pondrelli et al., 2002; Vičič et al., 2019), remote sensing, and field studies (e.g. Cunningham et al., 2007; Kastelic et al., 2008; Gosar et al., 2011; Moulin et al., 2014, 2016).

\subsection{Active tectonics}

The largest faults of the strike-slip Dinaric Fault System in the western part of this system are the Raša, Predjama, Idrija, and Ravne faults (Figs. 1-3). They accommodate N-S shortening by right-lateral strike-slip motion since the Pliocene (Žibret and Vrabec, 2016). The more than $120 \mathrm{~km}$ long Idrija Fault has the most prominent morphological imprint in the study area (Cunningham et al., 2006, 2007). It has a total right-lateral offset of around 10-12 km (Šušteršič, 1996; Placer et al., 2010) and an almost straight fault trace, pointing to its predominant strike-slip mechanism. Lower offset estimates $(\sim 2 \mathrm{~km})$ are based on the displacement of the mercury deposits, which were mined in Idrija for more than 500 years (Mlakar, 1964; Placer, 1982; Čar, 2010). The first geological evidence for the late Quaternary activity of the Idrija Fault came from faulted fluvial deposits in Kanomlja (Cunningham et al., 2006; Bavec et al., 2012) and in the Učja River valley (Vrabec, 2012). Geomorphological work showed that the fault offsets the regional drainage system and late Qua- 


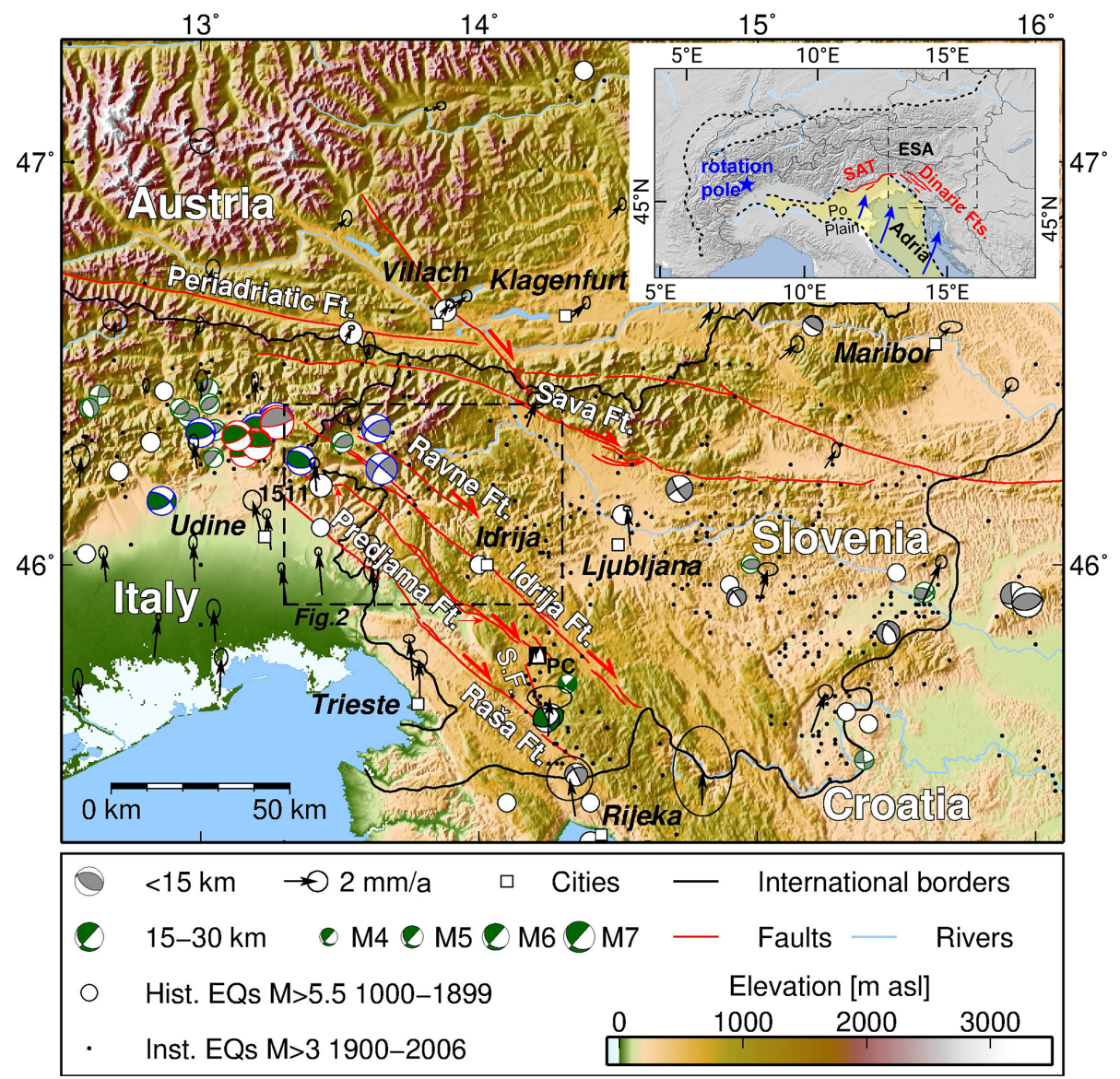

Figure 1. The study area in the Alps-Dinarides transition zone. Main faults of interest (red lines) are from Atanackov et al. (2021). Historical and instrumental seismicity are from the SHEEC database (Stucchi et al., 2013; Grünthal et al., 2013); the 1511 Idrija earthquake is marked (note that the location is uncertain; the earthquake probably occurred either on the Idrija Fault or on the SW side of the mountain front in Italy). Beach balls with black outlines are derived from $p$-wave arrivals (Herak et al., 1995); those with blue outlines are from quakes $M>5$ determined from first arrivals used in the Italian RCMT catalogue 1997-2017 (Pondrelli et al., 2002, and updates thereof); red outlines mark data from teleseismic body waveform inversion 1953-1984 (Anderson and Jackson, 1987); green outlines indicate data from Petersen et al. (2021) using the AlpArray seismic network. GPS data are from Metois et al. (2015) in a Eurasia-fixed reference frame. S.F.: Selce Fault; PC: Postojna Cave. Topography is from SRTM1 data. The inset shows the regional tectonic setting with the rotating and northward-moving Adriatic Plate. Dashed black lines indicate the main deformation fronts (after Bigi et al., 1990; Schmid et al., 2004, 2008; Froitzheim et al., 1996; Handy et al., 2010; Bousquet et al., 2012). Red lines indicate the south Alpine thrusts in the study area (SAT) and the Dinaric faults. ESA: eastern Southern Alps.

ternary morphological markers (Moulin et al., 2014, 2016). Moulin et al. (2016) estimated mean slip rates averaged over the last $255 \mathrm{kyr}$ of $1.15 \pm 0.15 \mathrm{~mm} / \mathrm{a}$ for the Idrija Fault using ${ }^{36} \mathrm{Cl}$ cosmic ray exposure dating. They also reported short-term $(\sim 15 \mathrm{kyr})$ slip rates for the Idrija Fault as high as $3.8 \pm 2.0 \mathrm{~mm} / \mathrm{a}$. However, recent fault slip rates are modelled to only $0.06-0.22 \mathrm{~mm} / \mathrm{a}$ (Kastelic and Carafa, 2012). Based on the mean slip rates and the total offset, Moulin et al. (2016) concluded that the strike-slip movement on the fault probably originated in the early Pliocene. In a metaanalysis, Atanackov et al. (2021) report a best estimate fault slip rate of $1 \mathrm{~mm} / \mathrm{a}$. Gosar (2020) used an extensometer to measure ongoing slip on a fault plane in the Učja River valley, but it remains unclear how this motion relates to the over- all fault kinematics. Around the city of Idrija, the Idrija Fault offsets mainly Triassic carbonate units and Permian rocks right-laterally.

The $\sim 75 \mathrm{~km}$ long Predjama Fault is estimated to have been active since the Middle Pleistocene, based on slip rates from geomorphic offsets and the total amount of slip (Moulin et al., 2016). It parallels the Idrija Fault but is not as straight and shows a prominent bifurcation at the Čepovan Canyon on the Trnovski Gozd Plateau. Moulin et al. (2016) estimated a slip rate of $1.45 \pm 0.25 \mathrm{~mm} / \mathrm{a}$ in the last $255 \mathrm{kyr}$ for the Predjama Fault based on offset morphological markers and ${ }^{36} \mathrm{Cl}$ dating. Atanackov et al. (2021) assigned an average slip rate of $0.7 \mathrm{~mm} / \mathrm{a}$ in their meta-analysis. In our study area, the Predjama Fault offsets Mesozoic carbonates by several hun- 


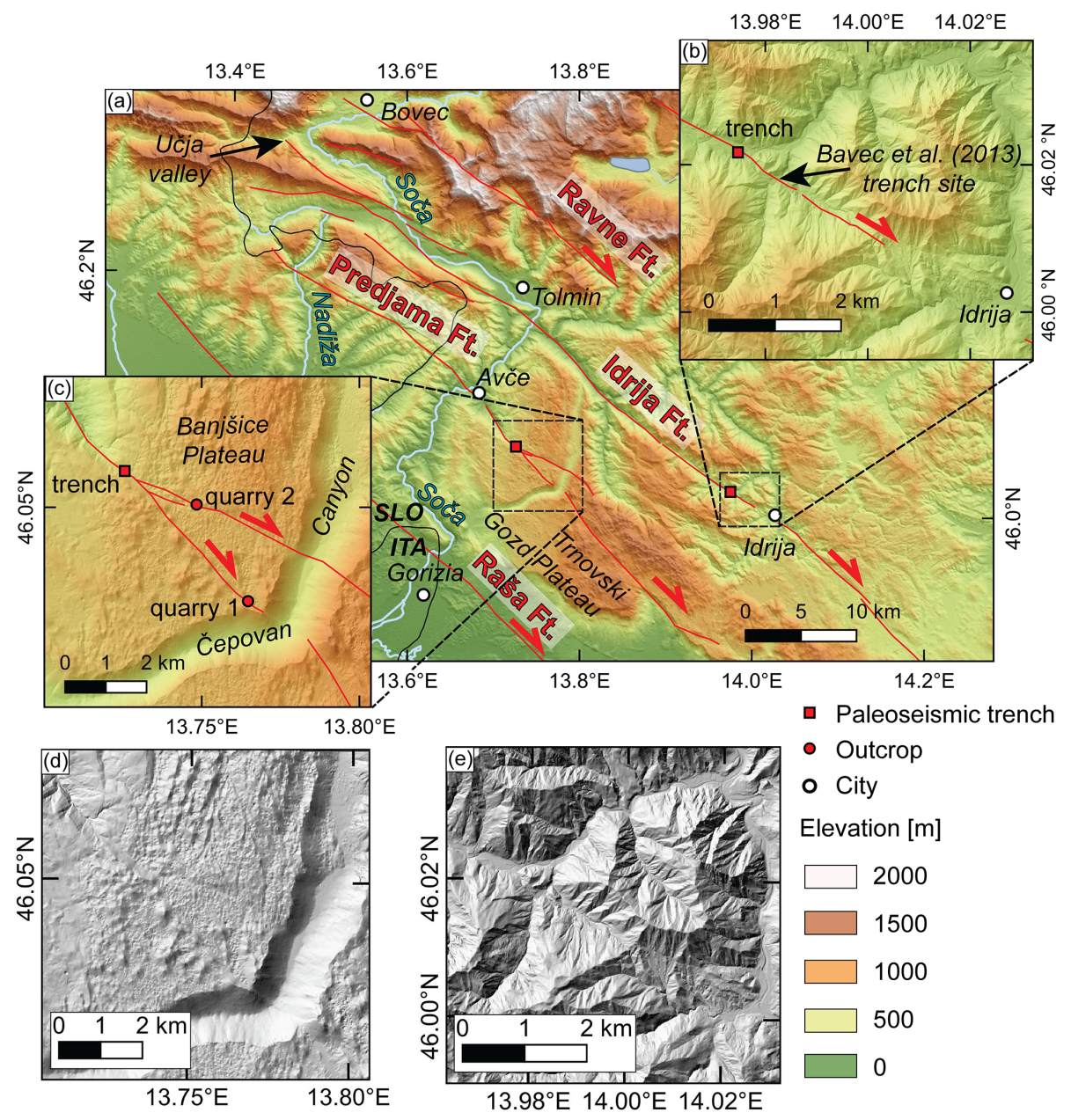

Figure 2. The study sites in NW Slovenia. Faults are from Moulin et al. (2016) and our own mapping. (a) Overview map (DEM from SRTM1). (b) At the Idrija Fault, the trench site is close to the one of Bavec et al. (2013). (c) At the Predjama Fault, we trenched the single strand section of the fault. (d) Hillshade of the Predjama Fault trench site. (e) Hillshade of the Idrija Fault trench site. In (b)-(e) the DEM is based on the $1 \mathrm{~m}$ lidar data.

dred metres right-laterally (Fig. 4). At the trench site, coralliferous limestones of Kimmeridgian to Oxfordian age are juxtaposed with Maastrichtian calcarenites.

GPS studies show that there is about $2-3 \mathrm{~mm} / \mathrm{a}$ of $\mathrm{N}-\mathrm{S}$ convergence of Adria vs. Europe at the longitude of the Eastern Alps (D'Agostino et al., 2005, 2008; Weber et al., 2010; Fig. 1) and a anticlockwise rotation of Adria about an Euler pole in the Western Alps of not more than $0.52^{\circ} / \mathrm{Myr}$ (Calais et al., 2002; Weber et al., 2010). This is in line with slip vectors of large earthquakes that occurred around the internally almost aseismic Adriatic Plate (Anderson and Jackson, 1987). As of today, the published GPS vectors in Slovenia are too coarse to allow for a more detailed analysis of single faults.

Large instrumental earthquakes with well-constrained fault plane solutions in the study area are rare. The 1976 Friuli sequence occurred on a N-dipping, E-W-trending thrust fault (e.g. Aoudia et al., 2000; Peruzza, 2002) at the southern Alpine front. Three earthquakes (beach balls with red outlines in Fig. 1) with magnitudes of 6.5, 6.0, and 6.1 (Aoudia et al., 2000) caused widespread damage. No surface rupture occurred, but a few centimetres of uplift were inferred from high-precision levelling and triangulation (e.g. Cheloni et al., 2012). Two shallow earthquakes of magnitude $M_{\mathrm{S}} 5.7$ and $M_{\mathrm{w}} 5.2$ occurred on the Ravne fault in 1998 and 2004, respectively (Bajc et al., 2001; Kastelic et al., 2004, 2008; Gosar, 2019a, b). The first event showed right-lateral strike slip on an almost vertical fault, which is also supported by structural observations from the field (Kastelic et al., 2008). The second event and its aftershocks also involved oblique right-lateral reverse mechanisms. A number of smaller earthquakes with right-lateral mechanisms occurred in the Slovenia-Croatia border area (Herak et al., 1995, 2009; Čarman et al., 2011; Jamšek Rupnik et al., 2016; Fig. 1). Vičič et al. (2019) relocated microseismicity data covering 2006-2017. They discovered swarm activity related 


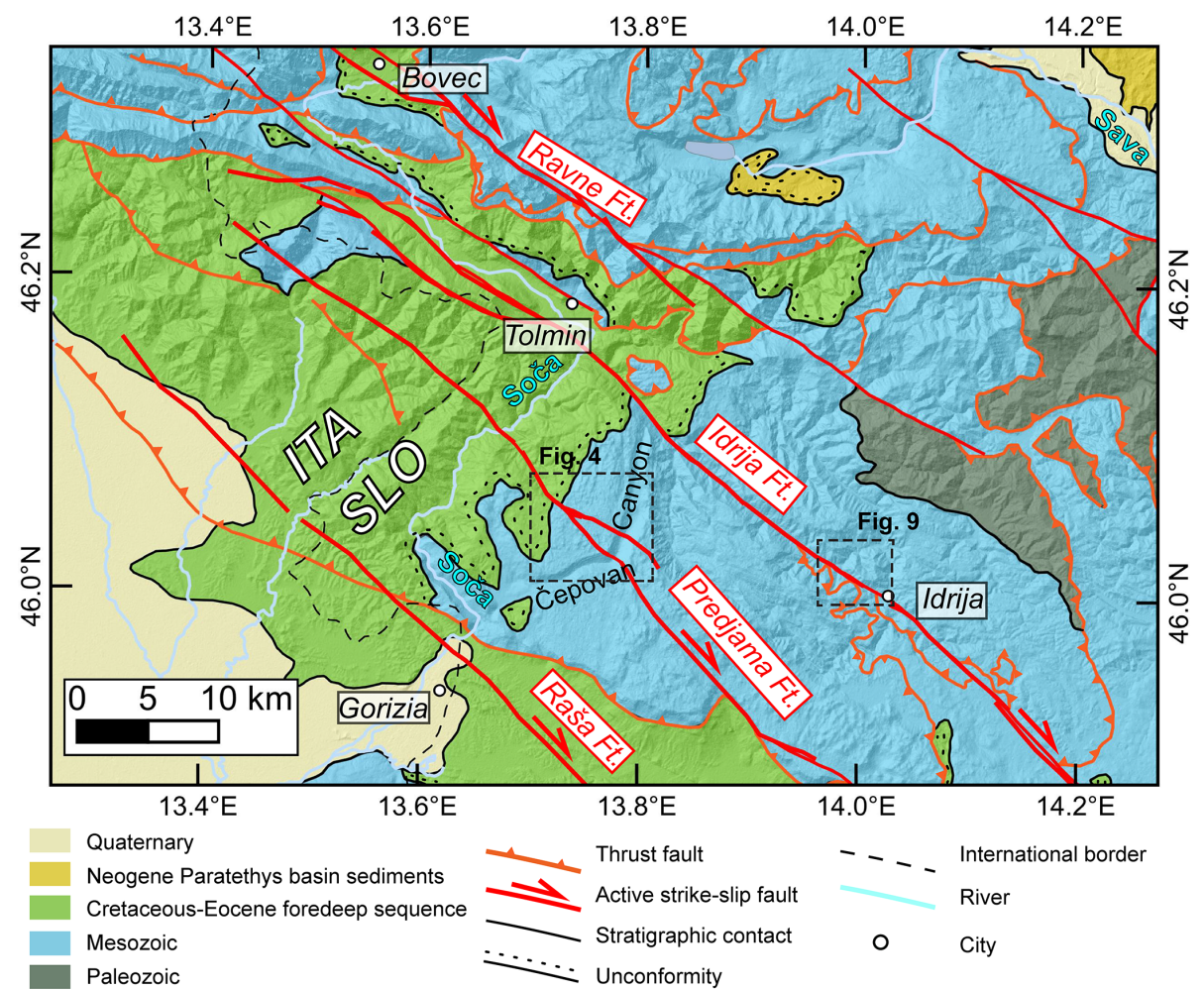

Figure 3. Geological setting of the study sites in NW Slovenia; same extent as Fig. 2. The geology is compiled from the $1: 250000$ geological map of Buser (2009) and the 1:150000 geological map of the Friuli Venezia Giulia region (Carulli, 2006).
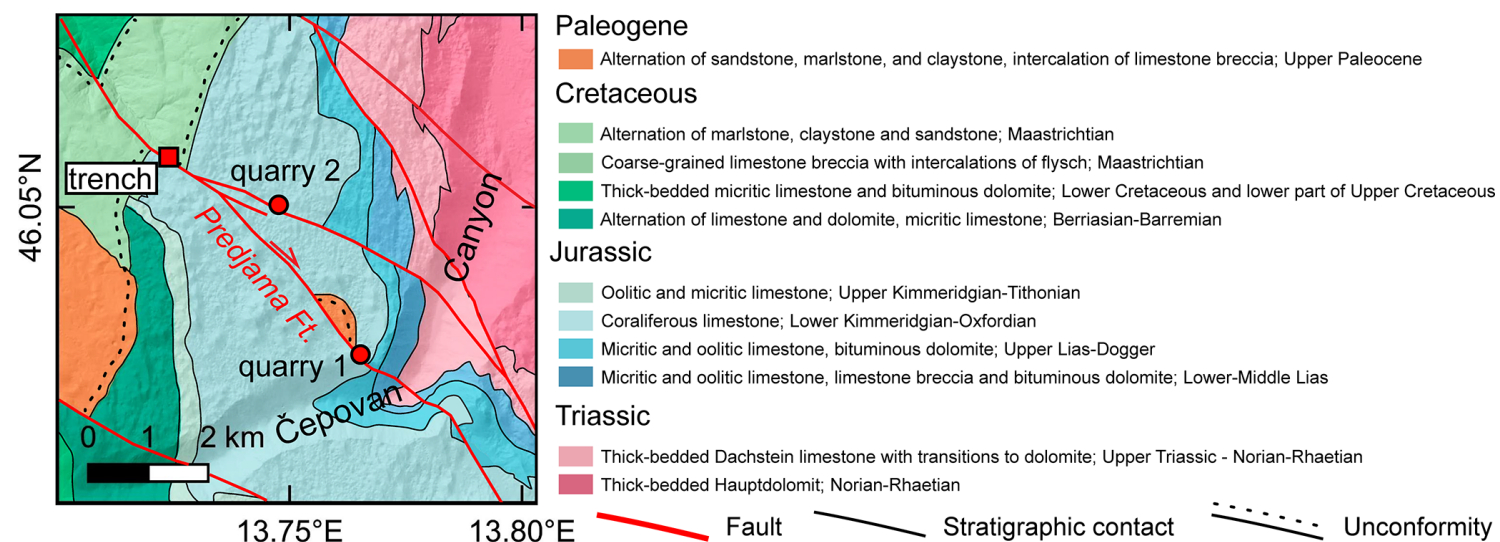

Figure 4. Geological map of the Predjama Fault trench site. Modified from the 1:250000 geological map of Buser (2009). Same extent as the inlet in Fig. 2.

to the Raša, Predjama, Idrija, Ravne, and Selce faults down to $20 \mathrm{~km}$ depth on almost vertical fault planes.

Historical seismicity in western Slovenia includes several earthquakes exceeding magnitude 5.5 (Ribarič, 1982; Albini et al., 2013, Fig. 1). None of the reported events can be conclusively tied to a specific fault, and there is no apparent clustering on any of the known active structures. Reliable historical data are mainly confined to the last 200 years (e.g. Herak et al., 2009, 2017, 2018; Cecić, 2015). Modelling of the macroseismic effects of the $1895 M_{\mathrm{w}} 6.1$ Ljubljana earthquake indicates that it occurred on one of the strike-slip faults that belong to the eastern part of Dinaric Fault System south of Ljubljana (Tiberi et al., 2018). The strongest historical event in western Slovenia was the 1511 Idrija earthquake (Ribarič, 1979; Fitzko et al., 2005; Cecić, 2011; Camassi et al., 2011). It devastated the mining town of Idrija in Slovenia and caused significant damage in NE Italy (see summary in Fitzko et al., 2005). Fitzko et al. (2005) modelled the macro- 
seismic data and found the best fit for a $50 \mathrm{~km}$ long rupture of the Idrija Fault, corresponding to a $M 6.9$ dextral strikeslip earthquake. This is supported by geophysical studies and a paleoseismic trench in the village of Srednja Kanomlja near Idrija (Bavec et al., 2012, 2013). However, Falcucci et al. (2018) trenched the Colle Villano Thrust in NE Italy and interpreted a post-15th-century surface-rupturing earthquake, which they interpret as the 1511 event. Thus, it is still not resolved whether the 1511 Idrija earthquake was a single event or if two earthquakes ruptured two different faults in close succession.

\section{Methods}

In order to identify the most promising sites for paleoseismological trenching, we first analysed the $1 \mathrm{~m}$ digital elevation model (DEM) of Slovenia (Ministry of the Environment and Spatial Planning, Slovenian Environment Agency, ARSO, 2019). These data are freely available for the entire country and were collected using lidar technology (light detection and ranging; airborne laser scanning). We manually inspected the mapped traces of the Predjama and Idrija faults and searched for offset geomorphic markers, breaks in slope, scarps, and similar indicators of recent tectonics. Then we identified sites with sediment archives that could have recorded large past earthquakes. For selected sites we acquired aerial images using a DJI Phantom 4 drone, which allowed us to compute high-resolution DEMs with up to $5 \mathrm{~cm}$ resolution using the structure-from-motion technique (SfM).

Geophysical surveys were then used to image the shallow subsurface and to precisely map the fault traces. All geophysical data are available online (Grützner et al., 2020). We used a ground-penetrating radar (GPR) system from Geophysical Survey Systems Inc (GSSI) with monostatic 100, 270 , and $400 \mathrm{MHz}$ antennas and a Pulse EKKO Pro Sensors \& Software system equipped with bistatic $250 \mathrm{MHz}$ antennas. All data were processed with the ReflexW software (Sandmeier Geophysical Research). Processing included frequency bandpass filtering, background removal, gain adjustments, and topographic corrections. The topographic data were extracted from the $1 \mathrm{~m}$ DEM.

Electric resistivity tomography (ERT) was performed with a 4point light system (Lippmann Geophysikalische Messgeräte). We used up to 80 electrodes with varying electrode spacing for Wenner, Schlumberger, and dipole-dipole arrays, depending on target resolution and depth. Data inversion was done with Res2DInv (Geotomo Software) and included manual de-spiking and topographic corrections.

Along several profiles we measured the vertical gradient of the geomagnetic field and the total magnetic field strength with a proton magnetometer GSM-19T (GEM Systems). The system consists of a rover and a base station, which allows correcting the data for diurnal variation. We used $1 \mathrm{~m}$ point spacing along several long transects.
Based on the geophysics results we selected one trench site at the Predjama Fault and one at the Idrija Fault. The trenches were excavated with a backhoe and their walls were cleaned and straightened. We installed a $1 \times 1 \mathrm{~m}$ string grid, sketched the walls in $1: 10$ scale, and produced 3D models and orthophotos of the trench walls using the SfM technique. Radiocarbon dating was performed by BETA Analytic on charcoal and bulk organic carbon samples.

\section{Results}

\subsection{Predjama Fault}

\subsubsection{Structural data}

In the area of the Čepovan Canyon the Predjama Fault mainly runs through Triassic and Jurassic carbonates (Fig. 4). Further to the northwest of the canyon, Maastrichtian calcarenites are present, which belong to the Cretaceous to Eocene foredeep sequence. The Predjama Fault trench site is located on the Banjšice Plateau, northwest of the Čepovan Canyon. In this area, a single fault trace is clearly visible in the DEM (Fig. 2). At Avče in the Soča Valley to the northwest of our trench site, Moulin et al. (2016) described a prominent change in valley topography caused by the fault (Fig. 2). The fault bifurcates just SE of our trench site and the two strands offset the cliffs of the Čepovan Canyon (Moulin et al., 2016). These authors also described a prominent vertical offset across the two fault strands. We found that slickensides in two quarry outcrops on the two strands (Fig. 2) show almost pure right-lateral strike slip on fault planes dipping steeply to the southwest (Fig. 5a-c). The fault zone is about $30 \mathrm{~m}$ wide in the second quarry (Fig. 5d). Both quarries exhibit Kimmeridgian-Oxfordian coralliferous limestones. To the southeast of the Čepovan Canyon, the two strands of the Predjama Fault cross the Trnovski Gozd Plateau, but only the southern fault trace continues further to the southeast (Fig. 2). We chose our trench site partly based on these observations in order to capture the entire slip of the fault on a single trace and to not miss significant portions due to its branching. About $70 \mathrm{~m}$ south of our trench site, Kimmeridgian-Oxfordian coralliferous limestones crop out in a large road cut, which runs parallel to the fault strike. These limestones are not intensely fractured and do not exhibit a fault zone. They only have a thin soil cover. According to the geological maps, Maastrichtian calcarenites are juxtaposed with the Jurassic limestones by the fault at this site (Fig. 4; Buser, 2009). We did not find any outcrop of the calcarenites near our trench site, but we encountered weathered and deformed calcarenites in the trench. We will describe these rocks in detail in Sect. 4.1.4. These observations indicate that the fault must run between the road outcrop and the trench site. 

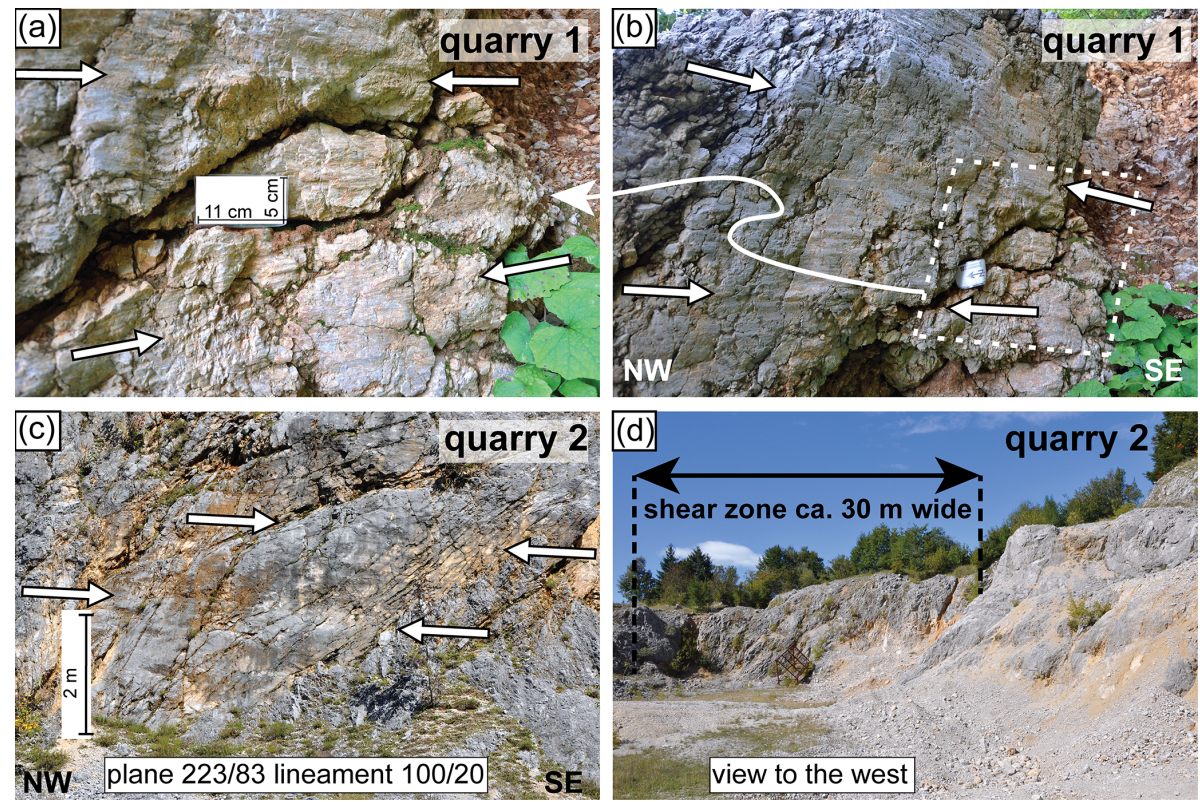

Figure 5. Quarries along the Predjama Fault; see Fig. 2 for location. Both quarries exhibit Jurassic coralliferous limestones. (a) At the southern strand of the fault, quarry $1\left(46.0299^{\circ} \mathrm{N}, 13.7632^{\circ} \mathrm{E}\right)$ exhibits $\mathrm{E}-\mathrm{W}$ lineaments with right-lateral shear sense on a fault plane dipping steeply to the southwest. (b) Larger section of the striated surface in quarry 1. (c) Large SW-dipping fault planes are present at the northern fault strand in quarry $2\left(46.0506^{\circ} \mathrm{N}, 13.7485^{\circ} \mathrm{E}\right)$. Slickensides show almost horizontal right-lateral motion. (d) In quarry 2 , the shear zone is ca. $30 \mathrm{~m}$ wide.

\subsubsection{Geomorphological observations}

At the trench site we observed a break in slope on a gently NE-dipping meadow (Fig. 6). The break in slope is detectable for $\sim 200 \mathrm{~m}$ (Fig. 6a). To the northwest and to the southeast of our trench site, the scarp disappears in the steep and forested terrain. Topographic profiles extracted from the $1 \mathrm{~m}$ lidar DEM and a $5 \mathrm{~cm}$ drone DEM reveal a systematic vertical offset of $\sim 0.5 \mathrm{~m}$ on an uphill-facing scarp. In some but not all places the scarp coincides with tracks used by the local farmers. Following the argument of Copley et al. (2018) the break in slope is unlikely to be caused by a dirt road (Fig. 6b). If the break in slope was solely caused by a dirt road, the break in slope would be local only. However, we find a systematic offset of the entire slope. Slovenian cadastre data from the early 19th century show no road, property boundary, or any other artificial feature at the location of the scarp. The area was the scene of the 12th Battle of the Isonzo in 1917. Here, the Italian defence lines were running $\sim \mathrm{N}-$ $\mathrm{S}$ just before the attack of the Austria-Hungarian armies on 24 October (Glaise von Horstenau, 1932). The Regional Archives Nova Gorica (Pokrajinski arhiv v Novi Gorici, https://www.pa-ng.si/, last access: 8 November 2018) hold no aerial photographs from World War I from our trenching area, but photos from nearby places on the Banjšice Plateau show intense modification of the surface by military trenches and bomb craters. We carefully inspected the available highresolution DEMs but did not find any indications of military action or installations that left their traces in the morphology. However, Valjavec et al. (2018) found that post-war landscape modifications have erased many traces of World War I in Slovenia. We also inspected the lidar data and the drone DEMs for evidence of landsliding or soil creep but did not find any such feature. The straight trace of the scarp, the systematic offset of the entire meadow, the lack of evidence for anthropogenic modification, and the fact that the scarp coincides with the mapped fault trace led us to interpret it as the surface expression of the Predjama Fault and to focus our geophysical prospection on this site.

\subsubsection{Geophysics survey}

We used GPR, ERT, and magnetic measurements on parallel profiles perpendicular to the scarp in order to check the subsurface conditions and to select the most promising trench site (Fig. 7). Georadar did not provide good data quality, which during trenching turned out to be due to highly conductive clayey sediments present near the surface. The geomagnetic data showed neither indications of the fault nor of metal objects in the ground, which indicates the lack of potentially dangerous war remains.

The dipole-dipole ERT data with $1 \mathrm{~m}$ electrode spacing show mainly resistivities of less than $70 \Omega \mathrm{m}$ throughout all profiles (Fig. 7). We interpret these low values as watersaturated, mainly clayey sediments. North of the break in slope we found $\mathrm{a} \sim 1 \mathrm{~m}$ thick layer with higher resistivities right below the surface in all profiles. Profiles 1-5 show val- 


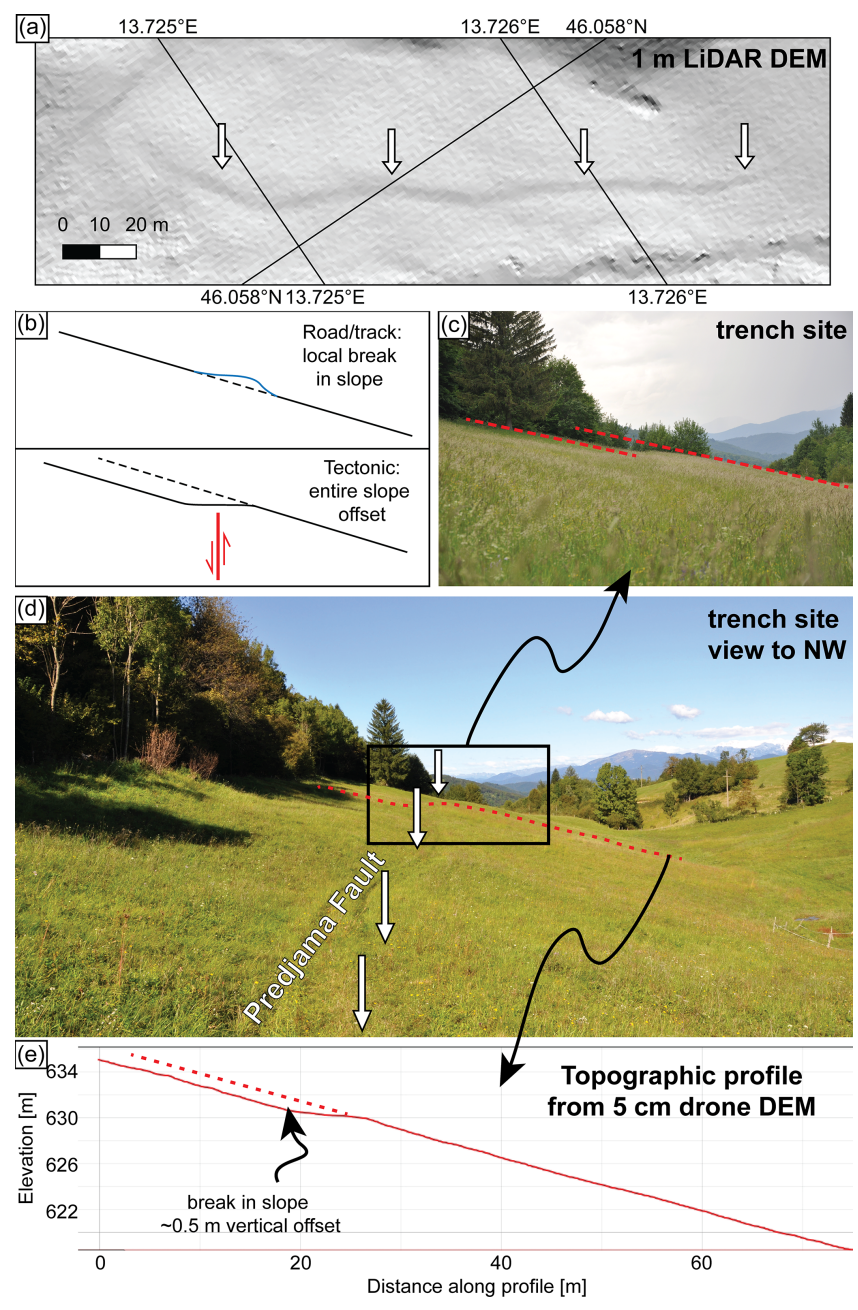

Figure 6. Morphology of the Predjama Fault at our trench site. (a) An uphill-facing break in slope can be traced for $\sim 200 \mathrm{~m}$ (white arrows; $1 \mathrm{~m}$ DEM lidar hillshade is illuminated from the northeast in this figure only). (b) Conceptual sketch illustrating the difference between a tectonic scarp and a local break in slope due to road/track construction (Copley et al., 2018). (c) A break in slope offsets the trench site. The red dashed lines show $\sim 0.5 \mathrm{~m}$ vertical offset. (d) NW view of the trench site (also see Fig. 6 for location). The red dashed line marks the location of the topographic profile in (e). Trench 1 was opened across this profile. (e) Topographic profile from a drone DEM with $5 \mathrm{~cm}$ resolution, illustrating the systematic offset of the slope and the uphill-facing scarp. This DEM is available at http://www.opentopography.org (last access: 26 March 2021).

ues of 100-200 $\Omega \mathrm{m}$ for this layer; profiles 6-10 show values of up to $400 \Omega \mathrm{m}$. These values likely correspond to a drier topsoil in the northern part of the profiles. This may be due to the greater thickness of clayey units in the northern parts, as we will see in the next section. In profiles 4-10 we observe another anomaly with increased resistivities at about $4 \mathrm{~m}$ depth just north of the break in slope. Based on the findings in the trenches (Fig. 8, File S1-S4 in the Sup- plement), we interpret this anomaly as calcarenites and limestones that were brought closer to the surface by the Predjama Fault. High resistivities were also encountered in profiles 6-9 at $\sim 3 \mathrm{~m}$ depth and below in the southernmost parts of the survey, which presumably correspond to bedrock (see trench logs in the next section). Paleoseismic trenching took place after the geophysical survey and helped to interpret the resistivity pattern. However, prior to trenching the significant variations in resistivity below the break in slope led us to conclude that we found the trace of the fault and that the site is suitable for further investigation. The break in slope does not always perfectly align with the resistivity contrasts at depth (Fig. 7). It is located a few metres to the north of the scarp in some (e.g. profile 8) but not all profiles (e.g. profile 10). Given that the Predjama Fault forms a $\sim 30 \mathrm{~m}$ wide fault zone in fault outcrops nearby (Fig. 5d), it is not surprising that the geophysical anomalies do not always perfectly align with the scarp. The resistivity contrast is not only visible in single profiles, but it is a consistent feature that can be traced for at least $60 \mathrm{~m}$ in consecutive profiles. The close spatial relation between the scarp and the geophysical anomalies indicates that we rightly located the Predjama Fault. We chose the location of profiles 5 and 7 to open two trenches (Figs. 7, 8; Files S1-S4).

\subsubsection{Paleoseismic trenching}

Trench 1 was $10 \mathrm{~m}$ long and on average $1.5 \mathrm{~m}$ deep (Fig. 8). Deeper excavation was prohibited by the shallow groundwater level. We distinguished seven units in both trench walls, most of which represent a rock weathering profile. Since both trench walls show comparable features, we use the northwestern trench wall for the detailed description in the following. We use the terms and weathering grades defined by ISRM (1981).

Unit U1 at the base of the trench consists of highly weathered calcarenites in a clayey matrix (grade IV). The rocks are intensely fractured; coherent bedding is only occasionally visible. While the $\mathrm{U} 1$ mainly consist of large clasts in the first $4 \mathrm{~m}$ of the trench, the weathering products dominate the upper parts of the unit between 5 and $8 \mathrm{~m}$. There is no sharp boundary between these two zones in the central part of the trench. However, the large amounts of fractured calcarenites there and the relationship to unit $\mathrm{U} 2$ require mapping it as U1. Occasionally, large and coherent but intensely fractured blocks of calcarenites are also present in the upper parts of $\mathrm{U} 1$. Because of their distinct appearance we mapped them as unit $\mathrm{U} 2$, representing moderately weathered rocks of grade III. Both units show a dip towards the northeast, parallel to the slope. On top of U1 and U2 sits a thin layer of compact grey clay: unit U3. This unit is a residual soil of grade VI. U3 is overlain by a thin red ribbon of sandy clay (unit U4) that mainly consists of moderately weathered calcarenites (grade III). Both U3 and U4 dip to the northeast. We interpret Units $\mathrm{U} 1-\mathrm{U} 4$ as a sequence of intensely weathered bedrock. 


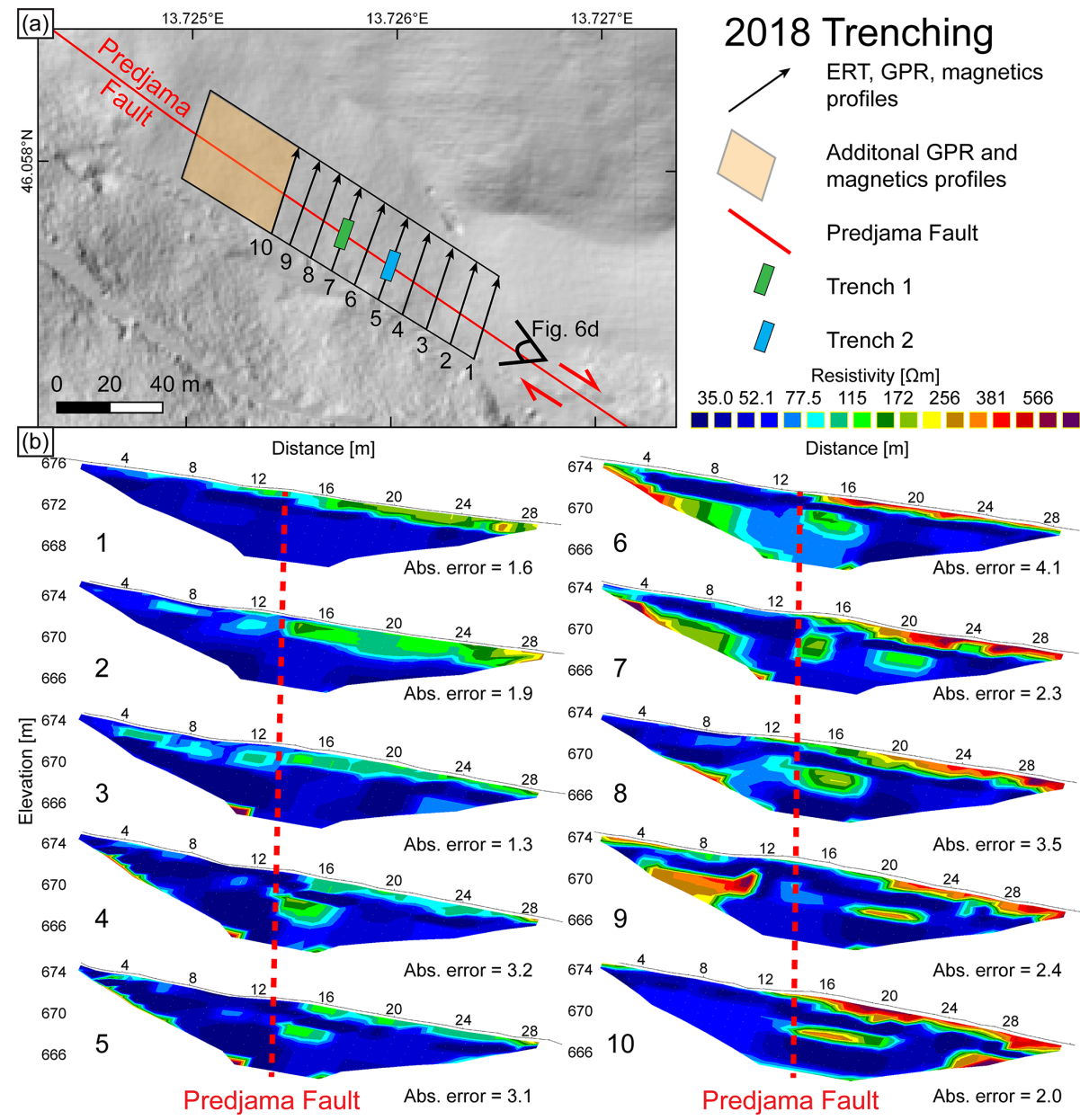

Figure 7. Map of the trench site at the Predjama Fault and ERT data. (a) Black arrows mark the location of geophysical profiles (ERT, GPR, magnetics). Additional GPR and magnetics data were collected further to the northwest. Seven iterations were used to invert the dipoledipole ERT data. The hillshade is based on the $1 \mathrm{~m}$ lidar DEM. (b) The ERT data show abrupt changes in resistivity below the break in slope, interpreted as the Predjama Fault trace (red dashed line). The absolute error describes the misfit between the data and the best-fit inverse model.

Most of the upper part of the trench is formed by a residual soil (grade VI) that forms massive brown clays (unit U5). The contact between U4 and U5 is sharp. Where U5 is in contact with U4, it contains small amounts of sand and fine gravels as well as fragments of charcoals. Small (fine gravel) calcarenite and limestone clasts are present throughout U5 in small amounts. Around $5 \mathrm{~m}$ in the trench, U5 is in contact with U1. Here the units U3 and U4 appear as lenses within U5, although they overlay U1 and U2 in the southwestern part of the trench. The pale, bleached clayey unit U6 with up to $30 \mathrm{~cm}$ thickness occurs just beneath the recent soil (unit U7). We note that unit U6 is not a sedimentary body, but a residual soil. The distinct pale appearance is likely just due to a modification of U5 by increased water content, or it may result from compaction due to the occasional use of the track by the farmers.

No sharp fault trace was found in the trench. Instead, we observe a zone of localised deformation at around 4-5 m dis- tance from the southern end of the trench. Unit U1 can be easily identified in the first $5 \mathrm{~m}$ of the trench. Around $5 \mathrm{~m}$ distance from the southern end of the trench, this unit bends down together with the overlying units U3 and U4. In a $40 \mathrm{~cm}$ wide gap unit U5 reaches the bottom of the trench. Unit U1 then occurs again between 5-6 $\mathrm{m}$ and between $6-8 \mathrm{~m}$ with up to $0.6 \mathrm{~m}$ thickness. It becomes gradually more weathered upwards and the contact with unit U5 is not sharp. The larger blocks of intact calcarenites that make up unit $\mathrm{U} 2$ are present throughout the trench and show no deformation.

Unit U3 is only visible in the southern section of the trench for about $2 \mathrm{~m}$. It has a more constant thickness of $10 \mathrm{~cm}$ in the SE wall of the trench and varies between 10 and $20 \mathrm{~cm}$ thickness in the NW trench wall. While this unit parallels the top of unit U1 for about $2 \mathrm{~m}$ from its southern end, it then bends down and dips steeply towards the northeast beneath the break in slope. Here we observe small folds in the tip of the layer. 


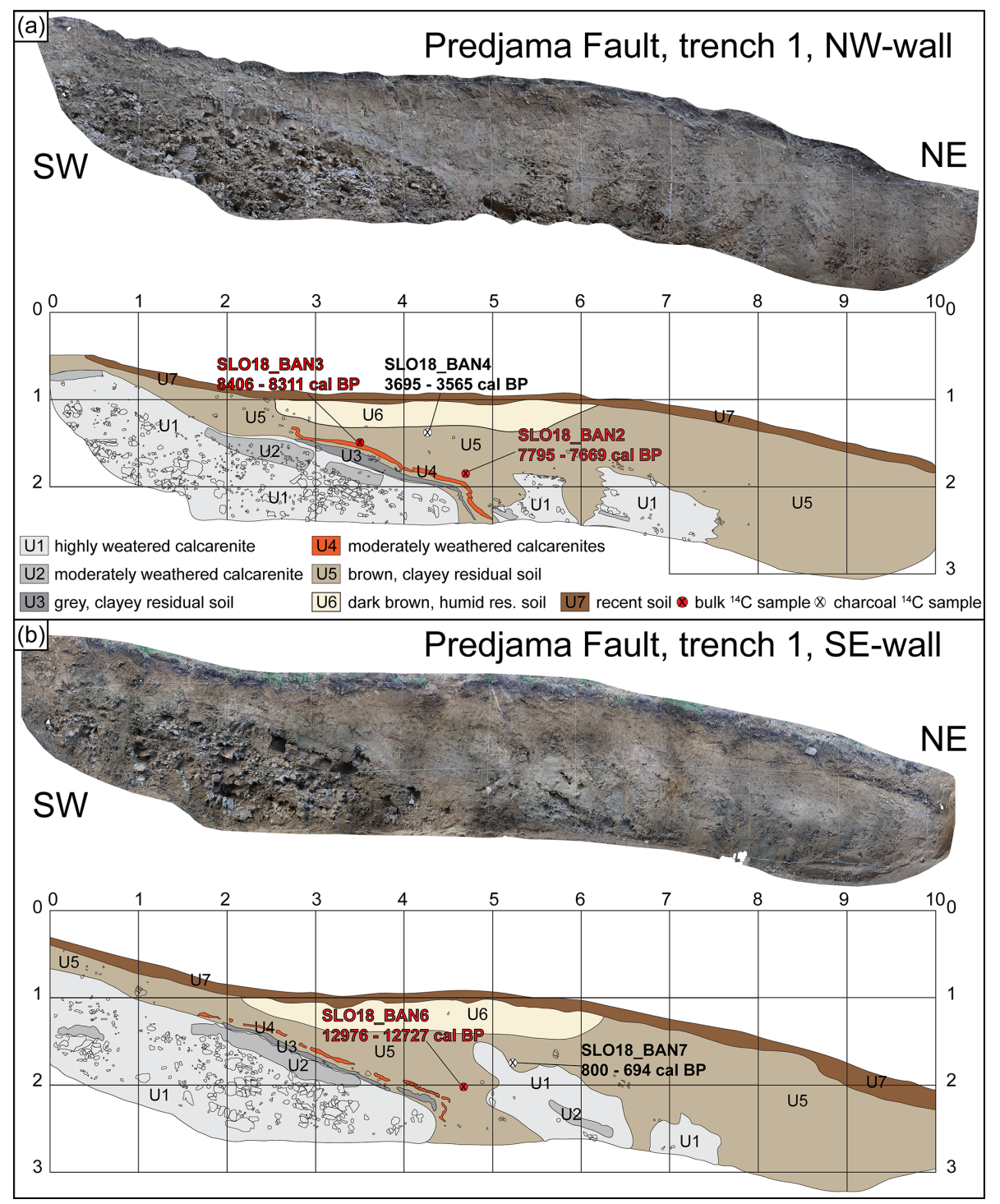

Figure 8. Paleoseismic trench 1 across the Predjama Fault on the Banjšice Plateau. (a) NW wall of the trench. The fault crosses the trench at $\sim 5 \mathrm{~m}$ distance. Note the folded units U3 and U4. (b) SE wall of the trench. The fault crosses the trench between $4 \mathrm{~m}$ and $5 \mathrm{~m}$ distance.

A similar feature is observed in unit $\mathrm{U} 4$, which also parallels U1 but then bends downward and becomes folded. Here we identified small horizontal faults with $<5 \mathrm{~cm}$ offset cutting the layer. The tip of the unit flattens again to almost the same dip angle as its southern part, with a vertical offset of $30 \mathrm{~cm}$. The few coarser grains at the contact between $\mathrm{U} 4$ and U5 show that the lowermost part of U5 also bends down parallel to U4.

Two scenarios could explain the observations in this trench: non-tectonic or tectonic processes. In the nontectonic scenario, the shape of $\mathrm{U} 3$ and $\mathrm{U} 4$ as well as the vertical offset in units $\mathrm{U} 1$ and $\mathrm{U} 2$ could be due to shallow-seated, slope-parallel motion, combined with phases of pedogenic development above the weathered bedrock units and perhaps additional oblique run-off processes. Arguments in favour of this scenario are the lack of a sharp fault zone in the trench and the fact that vertical motion is not expected on the strikeslip Predjama Fault. Arguments in favour of a tectonic process are (i) the lack of evidence for slope-parallel motion in the trench, such as shallow sliding planes, (ii) that the vertical separation of units $\mathrm{U} 1$ and $\mathrm{U} 2$ is not easily explained by gravitational processes only because the downslope side is uplifted, and (iii) the absence of evidence for run-off processes or slope-parallel motion in the two high-quality DEMs (1 $\mathrm{m}$ lidar and drone DEM). The slope is very smooth apart from the scarp; there are no landslide scars or "wrinkles" that may point to the toes of slides, etc. Since at least the upper units in the trench are of Holocene age as we will show in the following, we might expect to see such features in the morphology. Furthermore, although prevailing vertical motion is 
not expected, a vertical component of slip can be due to an irregular, bending fault trace.

The bending, the folding, and the faulting observed in the trench could be interpreted as tectonically induced (scenario 2). This interpretation is supported by the observation that $\mathrm{U} 3$ and $\mathrm{U} 4$ are intensely deformed in a relatively narrow zone, across which a vertical separation of $\mathrm{U} 1$ and $\mathrm{U} 2$ is observed. This zone at around $5 \mathrm{~m}$ would then represent the fault. This view is strengthened by the geomorphological and geophysical observations.

A sample of organic material from the contact between U4 and U5, sample SLO18_BAN3, gave an age of 84068311 cal BP (Table 1). Note that we sampled a fragment of charcoal, but during sample preparation in the lab it turned out to be too small, but it was possible to date the organic sediment around it.

We dated unit U5 with a bulk sample (SLO18_BAN2) from $10 \mathrm{~cm}$ above U4. This sample gave an age of 77957669 cal BP. A charcoal sample (SLO18_BAN4) from right below U6 provided an age of $3695-3565 \mathrm{cal}$ BP. All these ages are in stratigraphic order. On the opposite trench wall, we also dated U5 with a bulk sample (SLO18_BAN6) that returned an age of 12 976-12727 cal BP and a stratigraphically higher charcoal sample (SLO18_BAN7) that showed an age of 800-694 cal BP. These two samples are significantly older and younger than those of $\mathrm{U} 5$ on the NW trench wall, respectively.

Unit U6 can only be observed for around $4 \mathrm{~m}$ on either trench wall. It probably represents compacted residual soil of U5 resulting from the occasional use of the break in slope as a dirt road. Its age is constrained by samples SLO18_BAN4 and SLO18_BAN7 to post-800 cal BP. The full high-resolution trench orthophotos are presented in the Supplement.

Trench 2 exhibited a different stratigraphy. Here, we observed massive brown and grey, clayish residual soils beneath the modern soil but no calcarenites. Instead, the base of the trench at $\sim 2 \mathrm{~m}$ depth was made up in its southern part by limestone clasts in a brown clayey matrix, probably representing highly weathered bedrock (grade IV). Attempts to excavate deeper than $2 \mathrm{~m}$ were prohibited by the groundwater level. A possible fault zone in the centre of the trench is marked by a colour change in the clayey material and the termination of the limestone clast layer. However, the uniform clays and the lack of clearly deformed markers led us to not speculate about evidence for faulting in the trench. A highresolution orthophoto of both trench walls is provided in the Supplement.

\subsection{Idrija Fault}

The Idrija Fault trench site is located $4.5 \mathrm{~km}$ NW of the town of Idrija, in the valley of the Kanomljica River (Fig. 2). Here, the fault juxtaposes Upper Triassic with Lower-Middle Triassic rocks, mainly dolomites (Fig. 9; Mlakar and Čar, 2010).

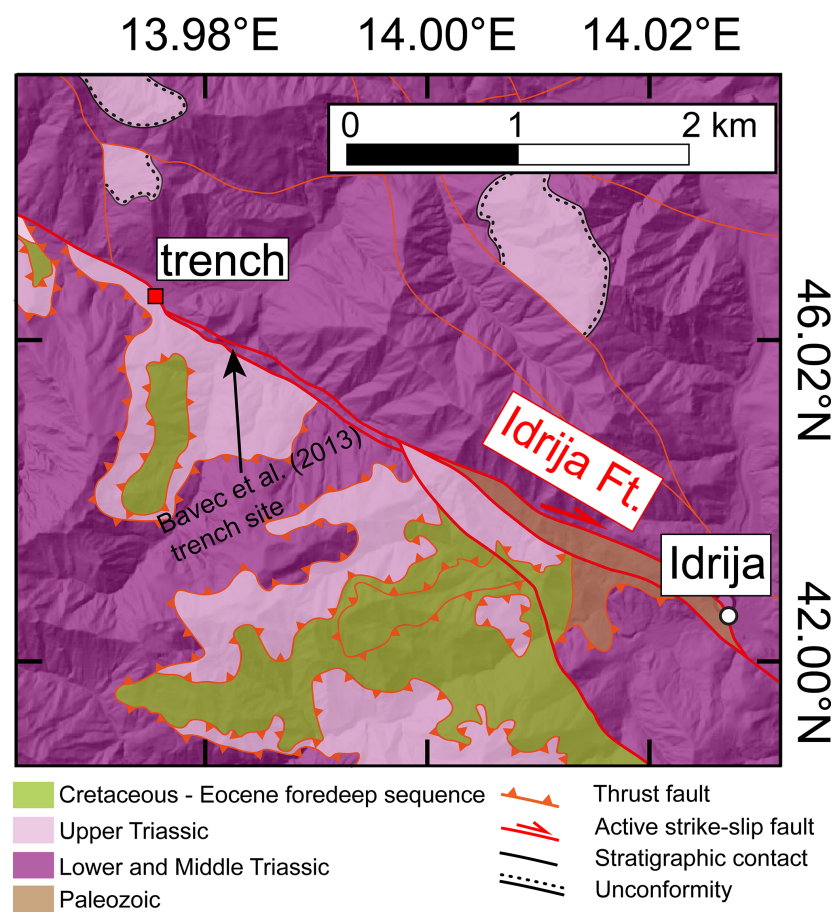

Figure 9. Geological map of the trench site at the Idrija Fault. Simplified from Mlakar and Čar (2010). Same extent as the inset in Fig. 2.

Cunningham et al. (2006) noted that several drainage anomalies around the Kapa hill just to the southwest of our trench site point to late Quaternary or even Holocene fault motion (Figs. 9, 10). Bavec et al. $(2012,2013)$ chose the river valley at the SW foot of the Kapa hill for a geophysics study and for a paleoseismological trench. Moulin et al. (2014) analysed the geomorphology in detail and reported between 340 and $380 \mathrm{~m}$ of right-lateral offset based on the correlation of the modern Kanomljica river and abandoned valleys. The precise trace of the Idrija Fault in the vicinity of our trench site is subject to some debate (Fig. 10; also see Moulin et al., 2014). The NW flank of the Kapa hill exhibits a wide shear zone with (ultra-)cataclastic rocks. This wide shear zone is in line with the observation that the Idrija Fault has a large cumulative offset (Čar, 2010; Placer et al., 2010). The trace of the fault in the wide valley of the Kanomljica is obscured by flat-lying fluvial sediments. Outcrops on the north side of the valley show that at least one fault strand clearly runs along the base of the hills (Moulin et al., 2014).

\subsubsection{Geophysics survey}

We concentrated our geophysical investigations on the flat area of the Kanomljica valley because we expected to find deformed sediments if the fault ruptured the surface in the late Quaternary (Fig. 10). Additional surveys were performed on the southern bank of the Kanomljica. The geomagnetics survey was not successful. Not only did the data quality suf- 


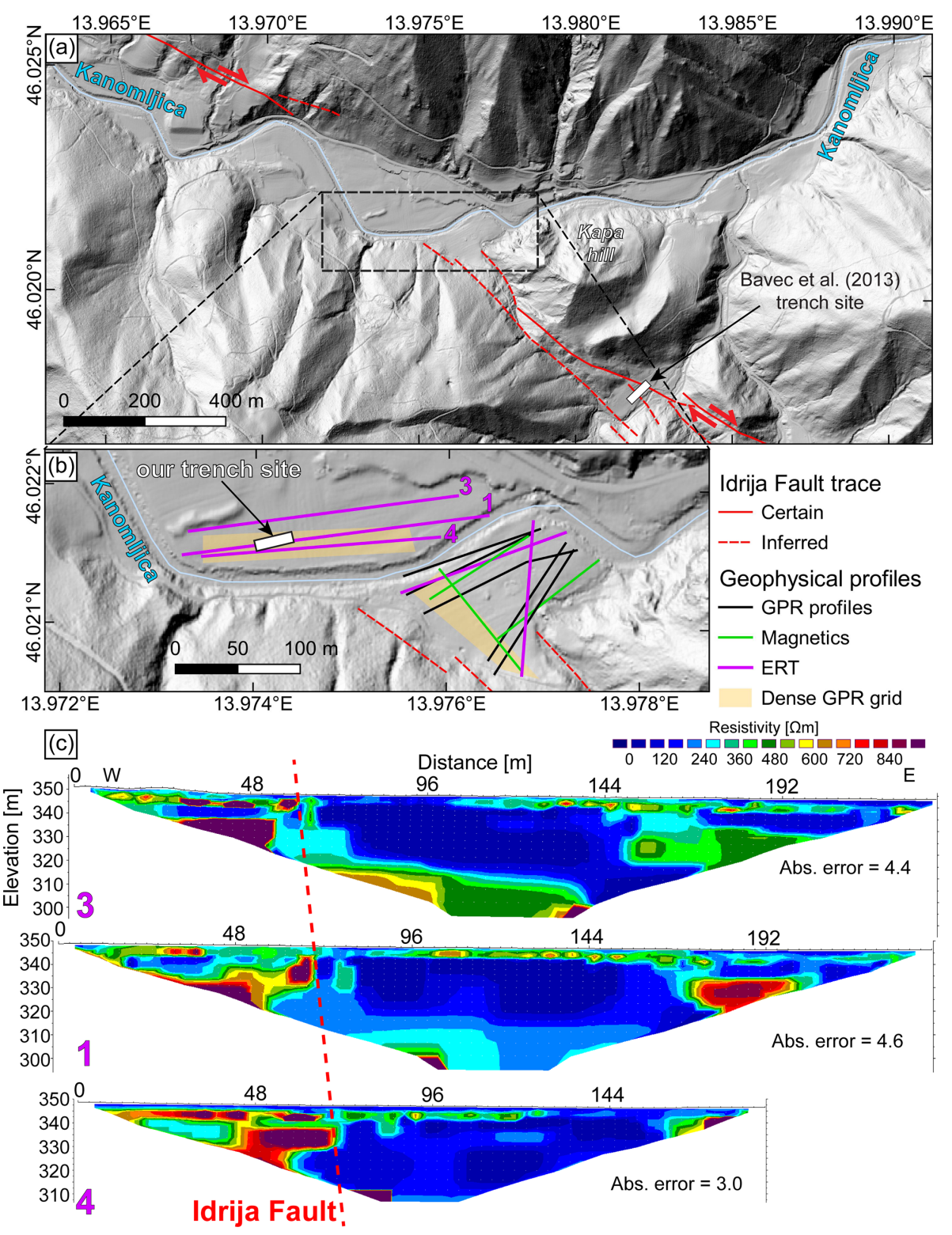

Figure 10. Map of the trench site at the Idrija Fault and selected ERT data. (a) Setting of the trench site and mapped traces of the Idrija Fault after Cunningham et al. (2006), Bavec et al. (2013), and Moulin et al. (2014). The precise fault trace is unknown in the flood plain of the Kanomljica River. (b) Detailed view of the location of all geophysical profiles used for trench site selection. (c) ERT profiles 1, 3, and 4, which were crucial for trench site location. Red dashed line indicates the interpreted fault trace. All data show dipole-dipole configuration with 10 iterations in the inversion. The absolute error describes the misfit between the data and the best-fit inverse model. In (a) and (b) the hillshade is based on the $1 \mathrm{~m}$ lidar DEM.

fer from the presence of power lines and other anthropogenic disturbances, but also in areas not affected by these effects we could not identify a signal pointing to a change in the subsurface structure. Georadar data suffered partly from low penetration depths owing to clay-rich sediments and a low groundwater table. Although some information on the geometry of the fluvial units could be extracted, we did not see any clear evidence for faulting that would have allowed for picking a promising trench site.
The ERT profiles on the flat surface north of the Kanomljica showed the clearest indication of the location of the Idrija Fault. For these profiles we used $3 \mathrm{~m}$ electrode spacing in order to reach great depths (Fig. 10). The uppermost part of the subsurface is made up of a mediumresistivity layer $(200-700 \Omega \mathrm{m})$ of about $3-5 \mathrm{~m}$ thickness, which likely corresponds to the sediment fill of the valley. In the trenches that we opened after the geophysics campaign we found that the sediments are dominantly coarse fluvial 
gravels and that the groundwater table is below $2 \mathrm{~m}$ depth. This explains the observed range of resistivities.

Below the medium-resistivity layer, the central parts of the profiles are characterised by an up to $30 \mathrm{~m}$ thick lowresistivity unit $(<200 \Omega \mathrm{m})$. The western parts of the profiles, however, show high-resistivity units of more than $700 \Omega \mathrm{m}$. The contact between the two is sharp and mostly vertical. In profiles 1 and 4, the contact is at $69 \mathrm{~m}$ profile distance. In profile 3 , the contact is at $60 \mathrm{~m}$. We interpret the low-resistivity unit as the crushed bedrock of the wide fault zone and the high resistivities as the intact, non-faulted bedrock. This is supported by our field observations of cataclastic rocks along the mapped and inferred fault trace. Furthermore, Bavec et al. (2012) found the same pattern in their geoelectric profiles SE of Kapa hill. Their trench (Bavec et al., 2013) confirmed the low resistivity of the faulted bedrock. These authors also found the active fault strand at the contact between the units of high and low resistivities. Consequently, we interpret the contact between the high-and low-resistivity units as the location of the fault. This contact lies in the projection of the inferred SW fault strand of Bavec et al. (2012). In the eastern parts of the three profiles presented in Fig. 6, sharp contacts between the low-resistivity units in the centre and medium to high resistivities (300-800 $\Omega \mathrm{m})$ further east can be seen. These zones are located at 170,150 , and $160 \mathrm{~m}$ distance in profiles 1,3 , and 4, respectively. The contacts do not align as well as the ones in the western part of our survey area, and they are located approximately in the projection of the NE fault trace (Fig. 10; Bavec et al., 2012). A power line was present above these parts of the profiles, which may have distorted the measurements here. However, we interpret this pattern as the NE edge of the inner fault zone following the reasoning above.

\subsubsection{Paleoseismic trenching}

Based on the ERT data we decided to open a trench across the sharp contact between the high-resistivity units and the low-resistivity units in the western part of the survey area (Fig. 10). The trench was $20 \mathrm{~m}$ long, $2 \mathrm{~m}$ deep, $2 \mathrm{~m}$ wide, and placed on the track of profile 1 . We did not dig any deeper because the nearby Kanomljica stream incised about $2 \mathrm{~m}$ into the flat valley bottom, and the groundwater table was located just beneath the trench floor. In the following we only describe the central part of the trench where we encountered traces of recent deformation. The full high-resolution trench orthophotos are presented in the Supplement.

In general, the trench is characterised by fine to coarse gravel deposits. In the centre of the trench, a channel exhibits clayey to sandy units. In the north wall, the channel can be seen between 5.5 and $12.5 \mathrm{~m}$ distance, reaching down to the trench floor (Fig. 11a). In the southern trench wall, the channel is observed between 4 and $14 \mathrm{~m}$ distance at up to $1 \mathrm{~m}$ depth (Fig. 11b).
We observed 11 different units in the trench. Unit U1 consists of clast-supported, fine-coarse fluvial gravels in a brown clayey matrix. This unit is present throughout the entire trench. Unit U2 is made up of mostly medium gravels in a bright red, clayey matrix. This layer is situated within unit U1 and only visible in the northern wall. Fine to coarse gravels in a light red clay matrix (unit U3) can be found as pockets in both trench walls within U1. We cannot rule out that $\mathrm{U} 2$ and $\mathrm{U} 3$ are the same unit, since it is only their colour that is different. At the base of the channel, we identified U4, consisting of sandy silt with yellow flakes. This unit is in vertical contact with massive grey clays (unit U5) and overlain by yellowish clayey gravels (unit U6). In the southern trench wall, U4 partly overlies U5, which may indicate that it has eroded into the latter. Only in the northern trench wall is a small pocket of grey clayey sands (unit U7) present at the contact between U1 and U8/U10. In the southern trench wall, silty-sandy, dark-grey unit U9 cuts through units U5 and U8. Both units U4 and U6 terminate at U9. Unit U9 is overlain by the darkest parts of U10, to which there is no sharp boundary.

Unit U10 consist of gravels in a matrix of grey clays. This unit overlies U7 in the northern trench wall and units U5 and U6 in the southern trench wall. The upper part of the channels is made up by unit U10. The lowest part of U10 is dark and rich in organics and made up of sandy clays. It changes upwards into massive grey and brownish clays with a minor gravel component. It is not possible to draw a sharp boundary between the dark, sandy clays and the greyish-brownish clays with gravel because the transition is gradual. However, these deposits must be mapped as one single unit because they clearly cover all the other fine and coarse units in the trench and because the internal changes are so gradual. We found white speckles at the base of U10 between 7 and $9 \mathrm{~m}$ distance ( $\mathrm{N}$ wall) and between 11 and $12 \mathrm{~m}$ distance in the southern trench wall. Unit U10 is overlain by the recent soil (unit U11).

We interpret most of the units in the northern trench as undisturbed fluvial sediments. Between 8 and $9 \mathrm{~m}$ distance, however, we observe several features that point to tectonically induced deformation. Units U4 and U6 show vertical terminations at their eastern ends, where they are in contact with U5. A charcoal sample dates U5 to 2140 1987 cal BP. The base of U5 fills the space between larger blocks (Fig. 11c). It remains unclear whether this resembles a fissure fill because of the lack of horizontally layered, fine-grained material here. Two bulk sediment samples from these lowest parts of U5 returned radiocarbon ages of 26452489 and 1528-1376 cal BP, respectively. Next to the base of U5 we encountered vertically aligned pebbles (Fig. 11c). This is the only occasion of aligned pebbles in the entire trench. Right above these pebbles sits a large $(\sim 40 \mathrm{~cm}$ diameter) clast that is intensely fractured but not offset. The cracks have no preferred orientation, and their surfaces show slightly different colours than those of fresh hand specimens that we hammered off the clast. The fractures were clearly 
not caused by the excavator. This is the only fractured clast that we have found in the trench. In the northern wall, U5 is overlain by U10, which was dated to 2307-2056 and 492315 cal BP by two charcoal fragments. Unit U8 resembles a pocket of coarse material emplaced into the clays of U10. We did not encounter any faults that bound U8, but we note its suspicious position above the aligned pebbles and the fractured clast. If units U2 and U3 were indeed the same unit despite their different colours (bright red vs. light red), there might be a vertical step of ca. $30 \mathrm{~cm}$ across the fault zone. However, we note that unit U3 also bends significantly without clear folding.

In the southern trench wall, only a narrow zone shows evidence for tectonic deformation between 11 and $12 \mathrm{~m}$ distance. Similar to the north wall, we observe vertical terminations of units $\mathrm{U} 4$ and $\mathrm{U} 6$. The most striking feature is the organic-rich, dark-grey U9. This unit is funnel-shaped and extends from the base of U10 about $1 \mathrm{~m}$ downwards. It is in vertical contact with $\mathrm{U} 4$ and $\mathrm{U} 6$, and it cuts through $\mathrm{U} 5$ and U8 (Fig. 11d). We interpret U9 as a fissure fill, with the filling material sourced from the base of U10. Unit U10 is the only one in the trench that also yields this dark layer rich in organics. This indicates that the fissure was filled from above and later became covered by the thick clays that make up the top part of unit U10.

If the fissure were instead a sand dyke that propagated upwards due to seismic shaking as opposed to surface rupture, we should see the source material of the dark fissure fill at its base, which is not the case. Furthermore, there is no evidence for liquefaction or soft sediment deformation structures elsewhere in the trench. These features may include flame structures, warped layers, mushroom structures, pseudonodules, broken layers, ball-and-pillow structures, etc., but none of these were observed here (also see the high-resolution photomosaics in the Supplement). For liquefaction to occur, a sequence of liquefiable, water-saturated layers is needed, but in our case the base of the trench exhibited coarse high-energy deposits. Our geophysics data hint at a rather thin sediment layer above fractured bedrock only. A similar observation was reported by Bavec et al. (2013) from their nearby trench site. We excavated the fissure U9 further into the trench wall to check if it may be due to a large root, but we found that the feature is elongated and not round as would be typical for roots. A bulk sediment sample from the fissure fill returned a radiocarbon age of 2378-2306 cal BP. A charcoal fragment from U5 was dated to 2067-1924 cal BP. At the base of U10 we collected a charcoal that gave an age of 2440-2315 cal BP.

\section{Discussion}

\subsection{Earthquakes on the Predjama Fault}

Paleoseismological trenching at the Predjama Fault provided evidence that could be interpreted as Holocene activity because the weathered units are deformed. Thus, the deformation can be interpreted as post-dating the formation of the base of U5. Alternatively, slope processes and pedogenesis could have led to the features observed in the trench. Combined with geomorphological data and geophysical prospection two main observations support the view in favour of a recent surface-rupturing seismic event: (i) the uphill-facing scarp and (ii) the folded and faulted units in the trench. The detectable break in slope is rather short $(\sim 200 \mathrm{~m})$, but it perfectly matches the mapped fault trace, it is located right above the geophysical evidence of faulting, and an anthropogenic origin is as unlikely as a mass movement (cf. Copley et al., 2018). Notably, the break in slope was used as a local track for agricultural purpose, but we can exclude the possibility that it solely represents a road (Fig. 6b, c, e). The bend in the trace of the Predjama Fault at our trench site (Fig. 2, inset) leads to a locally transpressive regime, which allows for significant vertical offsets. Moulin et al. (2016) also describe the long-term vertical offset along the Predjama Fault between our trench site and the Čepovan Canyon. However, our structural data, long-term offsets at the edge of the Čepovan Canyon (Moulin et al., 2016), and vertically aligned microseismicity below the fault trace (Vičič et al., 2019) show that the fault is predominantly, albeit not purely, strike slip.

In addition to the morphological evidence, the trench (Fig. 8) exhibits features that could be interpreted as faultperpendicular shortening. In the northern trench wall, we observe a vertical step of $\sim 0.4 \mathrm{~m}$ in unit U1 between 4 and $5.5 \mathrm{~m}$ distance (north side up, same as the scarp). In the southern trench wall, this step is harder to measure because unit $\mathrm{U} 1$ does not have a sharp boundary. The offset of unit $\mathrm{U} 2$ is the better marker here and indicates $\sim 0.6 \mathrm{~m}$ of vertical offset between 4 and $6 \mathrm{~m}$ distance. In such a setting one might expect a drag fold geometry. In our trench we observe the opposite. This could either indicate that non-tectonic processes were involved in the deformation or that an unknown amount of lateral motion has contributed to the observed geometry. In the first case, it is hard to imagine a process that would lead to such a configuration and also result in a $\sim 200 \mathrm{~m}$ long scarp. Lateral motion, however, can juxtapose units that were originally located at different depths and lead to complicated deformation patterns as a result of transpression. Our data do not allow further speculation on the cause. The location of the deformation zone fits in well with the presence of U6 on top of the deformation zone. Unit U6 is most likely nothing but a compacted and more humid U5 due to the occasional use of the break in slope as a dirt road; the local farmers might have taken advantage of the morphological scarp. The offsets also fit in with the height of the scarp as seen in the 


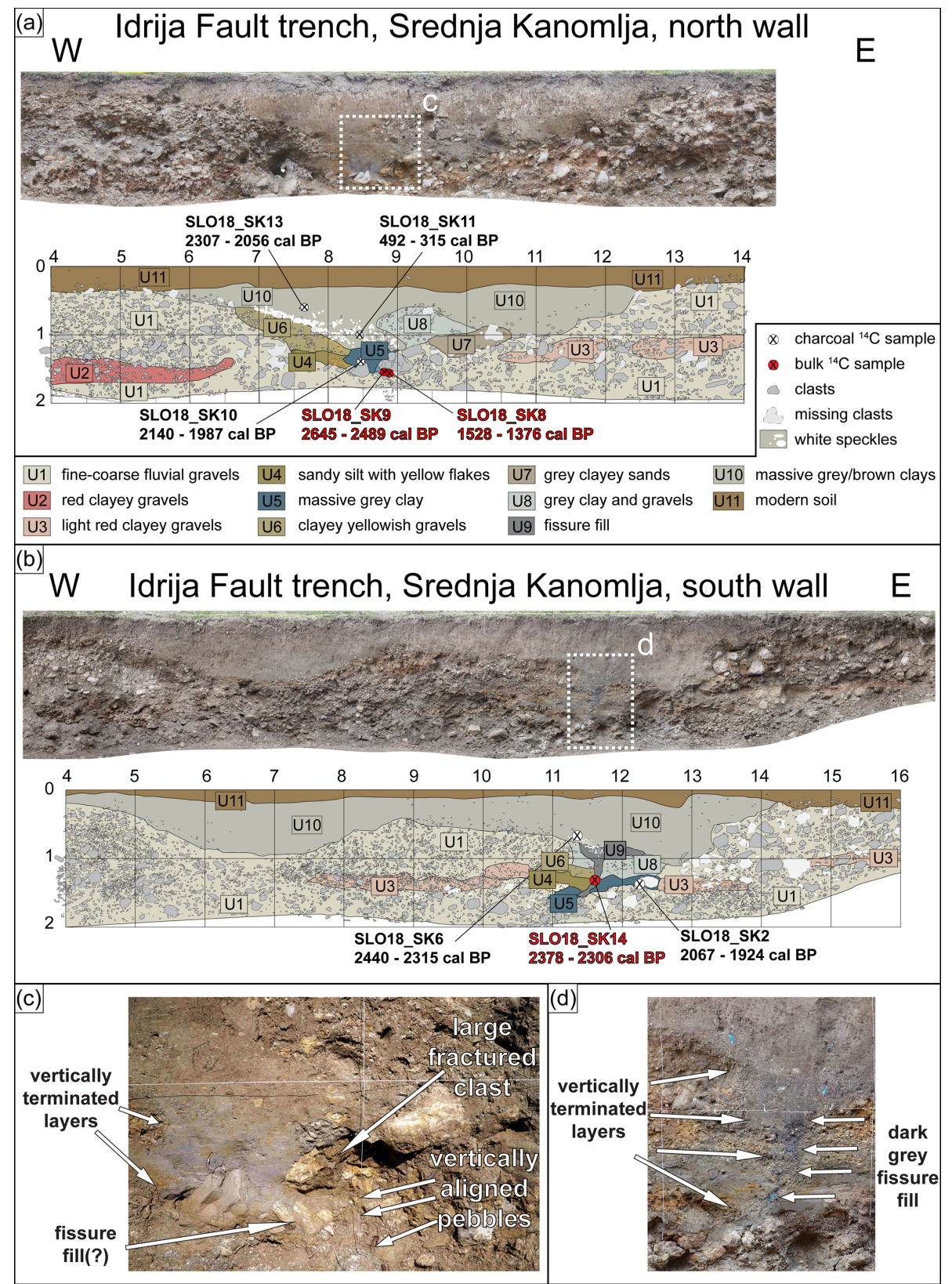

Figure 11. Results from the Idrija Fault trench at Srednja Kanomlja. (a) Orthophoto and trench log of the northern trench wall. (b) Orthophoto and trench $\log$ of the southern trench wall. Note that the photo and log have been flipped for easier comparison with the northern wall. (c) Close-up photo of the fault zone in the northern trench wall. Note the vertically terminated layers and the aligned pebbles below the massive, fractured clast. (d) Close-up photo of the fault zone and the fissure fill observed in the southern trench wall.

morphology, which speaks against non-tectonic processes as the cause. Both trench walls show folding, minor-scale faulting, and a downward bend of the prominent reddish marker horizon, unit U4.

The observed deformation could also be explained by shallow-seated mass movements or soil creep. Pedogenic development above the weathered bedrock units could have contributed to the apparent deformation, perhaps aided by oblique run-off processes. However, there is no geomorpho- logical observation that would support this view. The geophysics show that there is a fault zone beneath the trench site, although this does not necessarily mean that it caused the deformation in the trench. Although we cannot pin down the exact fault trace, the sharp breaks in unit U4 point to rapid shortening. We argue that there are better arguments in favour of tectonic deformation and that the fault has had at least one recent surface-rupturing earthquake. The lack of clearly identifiable, thin sedimentary layers makes it impos- 
Table 1. Summary of all dated samples. Probability was calculated after Bronk Ramsey (2009). Calibration was done with INTCAL13 (Reimer et al., 2013).

\begin{tabular}{|c|c|c|c|c|c|c|}
\hline Sample ID & Fault & Trench & Material & $\delta^{13} \mathrm{C}$ & Conventional age & Calibrated age (probability) \\
\hline SLO18_SK2 & Idrija & S wall & Charcoal & $-25.3 \%$ & $2040 \pm 30 \mathrm{BP}$ & $\begin{array}{l}2067-1924 \mathrm{cal} \mathrm{BP}(88.1 \%) \\
2111-2080 \mathrm{cal} \mathrm{BP}(6.8 \%) \\
1907-1904 \mathrm{cal} \mathrm{BP}(0.5 \%)\end{array}$ \\
\hline SLO18_SK6 & Idrija & S wall & Charcoal & - & $2340 \pm 30 \mathrm{BP}$ & $\begin{array}{l}2440-2315 \mathrm{cal} \mathrm{BP}(94.5 \%) \\
2456-2449 \mathrm{cal} \mathrm{BP}(0.9 \%)\end{array}$ \\
\hline SLO18_SK8 & Idrija & $\mathrm{N}$ wall & Organic sediment & - & $1550 \pm 30 \mathrm{BP}$ & $1528-1376 \mathrm{cal} \mathrm{BP}(95.4 \%)$ \\
\hline SLO18_SK9 & Idrija & $\mathrm{N}$ wall & Organic sediment & $-27.4 \%$ & $2510 \pm 30 \mathrm{BP}$ & $\begin{array}{l}2645-2489 \mathrm{cal} \mathrm{BP}(67.7 \%) \\
2740-2650 \mathrm{cal} \mathrm{BP}(27.7 \%)\end{array}$ \\
\hline SLO18_SK10 & Idrija & $\mathrm{N}$ wall & Charcoal & $-25.4 \%$ & $2080 \pm 30 \mathrm{BP}$ & $\begin{array}{l}2140-1987 \mathrm{cal} \mathrm{BP}(94.5 \%) \\
1958-1952 \mathrm{cal} \mathrm{BP}(0.9 \%)\end{array}$ \\
\hline SLO18_SK11 & Idrija & $\mathrm{N}$ wall & Charcoal & $-24.9 \%$ & $350 \pm 30 \mathrm{BP}$ & $\begin{array}{l}412-315 \mathrm{cal} \mathrm{BP}(54.2 \%) \\
492-420 \mathrm{cal} \mathrm{BP}(41.2 \%)\end{array}$ \\
\hline SLO18_SK13 & Idrija & $\mathrm{N}$ wall & Charcoal & $-24.5 \%$ & $2160 \pm 30 \mathrm{BP}$ & $\begin{array}{l}2208-2056 \mathrm{cal} \mathrm{BP}(55.4 \%) \\
2307-2228 \mathrm{cal} \mathrm{BP}(40 \%)\end{array}$ \\
\hline SLO18_SK14 & Idrija & S wall & Organic sediment & $-28.3 \%$ & $2320 \pm 30 \mathrm{BP}$ & $\begin{array}{l}2378-2306 \text { cal BP }(89.9 \%) \\
2235-2184 \text { cal BP }(5.5 \%)\end{array}$ \\
\hline SLO18_BAN2 & Predjama & T1, NW wall & Organic sediment & $-24.0 \%$ & $6900 \pm 30 \mathrm{BP}$ & $7795-7669 \mathrm{cal} \mathrm{BP}(95.4 \%)$ \\
\hline SLO18_BAN3 & Predjama & T1, NW wall & Organic sediment & - & $7530 \pm 30 \mathrm{BP}$ & $\begin{array}{l}8406-8311 \mathrm{cal} \mathrm{BP}(93.9 \%) \\
8235-8221 \mathrm{cal} \mathrm{BP}(1.5 \%)\end{array}$ \\
\hline SLO18_BAN4 & Predjama & T1, NW wall & Charcoal & $-23.2 \%$ & $3380 \pm 30 \mathrm{BP}$ & $3695-3565 \mathrm{cal} \mathrm{BP}(95.4 \%)$ \\
\hline SLO18_BAN6 & Predjama & T1, SE wall & Organic sediment & $-23.8 \%$ & $10980 \pm 40 \mathrm{BP}$ & $12976-12727$ cal BP $(95.4 \%)$ \\
\hline SLO18_BAN7 & Predjama & T1, SE wall & Charcoal & $-24.5 \%$ & $860 \pm 30 \mathrm{BP}$ & $\begin{array}{l}800-694 \text { cal BP }(83.5 \%) \\
901-866 \text { cal BP }(9.9 \%) \\
826-814 \text { cal BP }(2 \%)\end{array}$ \\
\hline
\end{tabular}

sible to decide whether only one event or several earthquakes were recorded in the trench.

\subsection{Dating of the Predjama Fault earthquake(s)}

In this section we first consider the tectonic interpretation of the trenching results. In the northern trench wall, all three radiocarbon samples are in stratigraphic order (Fig. 8, Table 1). The stratigraphically lowest sample from U4, sample SLO18_BAN3, was submitted as a charcoal, but in the lab, it turned out that the sample size was very small and that only the surrounding organic sediment could be treated. This sample, however, gave an age of 8406-8311 ka cal BP (Table 1) and dates the start of pedogenesis of the weathered bedrock. Bulk sample SLO18_BAN2 is located just a few centimetres above U4 and returned a slightly younger age of 7795$7669 \mathrm{cal}$ BP. Taken together, these two samples indicate that the deformation happened after $\sim 8.4$ ka because $\mathrm{U} 4$ and the base of U5 are deformed. Charcoal sample SLO18Ban_4 has an age of 3695-3565 cal BP and most likely post-dates the deformation.
In the southern trench wall, a bulk sample from unit U5 close to the deformation zone gave an age of 1297612727 cal BP (SLO18_BAN6). The stratigraphically higher sample SLO18_BAN7 (charcoal) is much younger with an age of 800-694 cal BP. While samples SLO18_BAN2 and SLO18_BAN3 are consistent, sample SLO18_BAN6 is much older than those two but should give a similar age. This can either be explained by the inherent large uncertainties related to the dating of bulk samples (e.g. Wang et al., 1996; Howarth et al., 2018; Langridge et al., 2020) or by the (unknown) lateral component of fault motion that juxtaposes units of different ages. Likewise, the two charcoal samples SLO18_BAN4 and SLO18_BAN7 are 3 kyr apart, although they were expected to give similar ages. One explanation is that the older sample has a residence time issue; that is, the charcoal could stem from an old tree, and it could have rested somewhere upslope before deposition in the present-day location (see discussion in Zachariasen et al., 2006). Another explanation is again the unknown lateral component of fault motion. Post-glacial pedogenic processes might be responsi- 
ble for the widely scattered bulk radiocarbon ages, but this does not apply to the dated charcoals. The most conservative approach for bracketing the age of the observed deformation is to use the oldest and the youngest samples, which would place the earthquake(s) between 13-0.7 ka. However, the good agreement of the samples in the northern trench wall leads us to speculate that the deformation actually happened after $8.4 \mathrm{ka}$. The young age of sample SLO18_BAN7 could explain why the scarp is still preserved.

In the non-tectonic scenario, the deformation could have happened in many phases since, or even partly prior to, $13 \mathrm{ka}$.

\subsection{Earthquakes on the Idrija Fault}

Our ERT data show that the strong vertical resistivity contrasts are situated along-strike of the mapped Idrija Fault trace, and we found deformation structures at this very location in the paleoseismological trench. This leads us to conclude that we rightly identified the recently active fault trace. Four main observations from the trench are evidence for earthquake faulting in the Holocene: (i) the filled fissure, (ii) the vertical terminations of fluvial sediments, (iii) vertically aligned pebbles, and (iv) a large, fractured clast. These four features were all found in a narrow zone that aligns with the mapped fault trace.

The fissure in the southern trench wall cuts through units U5 and U8. Units U4 and U6 terminate at the fissure. This geometry cannot be explained by sedimentary processes. The termination of layers in the southern trench wall probably results from lateral shifts of sedimentary bodies due to strikeslip motion on the fault. The fill consists of dark organic material that is also present above the fissure at the base of unit U10. Therefore, we interpret that an open crack formed due to faulting in a strong earthquake and that the material present at the surface fell in and filled the crack relatively quickly. We consider it unlikely that the fissure was caused by lateral spread or a failure of the riverbanks, perhaps due to seismic shaking because the fissure is only localised and lacks a sliding horizon at its base. Also, no indications of liquefaction were observed. The trench lacks any evidence for typical secondary soft sediment deformation structures such as flame structures, warped layers, mushroom structures, pseudonodules, broken layers, or ball-andpillow structures. Recent examples of lateral spread show extensive cracks with large offsets that occur due to the shaking and often also in combination with liquefaction (e.g. Papathanassiou and Pavlides, 2007; Hayes et al., 2010; Cubrinovski et al., 2012). Instead, the fissure that we observe could resemble en echelon ruptures in a strike-slip earthquake, as has been frequently observed in recent events (cf. Sylvester, 1988; Treiman et al., 2002; Talebian et al., 2004; Duman et al., 2005; Audemard, 2006; Barrell et al., 2011; Choi et al., 2018; Little et al., 2021). This would explain why we did not observe a similar feature in the northern trench wall.
In the northern trench wall, we observed not only the vertically terminated layers but also aligned pebbles and a large, fractured clast. Aligned pebbles are described from many faults cutting through sediments world-wide (e.g. Hooyer and Iverson, 2000; Vanneste and Verbeeck, 2001; Sapkota et al., 2013; Patyniak et al., 2017; Zabc1 et al., 2017). However, they are sometimes also related to liquefaction (e.g. McNeill et al., 2005), for which we do not find evidence. Although we found aligned pebbles only in one place in our trench, their location fits perfectly with the other indicators of active faulting. Right above these aligned pebbles we found the only ruptured clast of the trench. Such ruptured clasts in a fault zone surrounded by intact clasts have been described from faults around the world (e.g. Atwater, 1992; Radjai et al., 1998; Alfaro et al., 2001; Thakur and Pandey, 2004; Silva et al., 2009; Agosta et al., 2012; Tokarski and Strzelecki, 2020; Tokarski et al., 2020). If the broken clast were due to gelifraction, we would expect to find many fractured rocks and not only one right in the fault zone (see Bertran et al., 2020). The fact that only one clast broke indicates that the fractures were not caused by the regional stress regime (cf. Ramsay, 1964; Eidelman and Reches, 1992). Similarly, it is unlikely that the river transported only one clast with cemented voids that later dissolved at the trench site. We conclude that all the observations described above prove a tectonic origin of the observed features.

\subsection{Dating of the Idrija Fault earthquake}

In the northern trench wall, we obtained two radiocarbon ages from bulk organic material below the fractured clast (Fig. 7). Sample SLO18_SK8 gave an age of 15281376 cal BP; sample SLO18_SK9 returned an age of 26452489 cal BP. These two ages differ by at least $1 \mathrm{kyr}$, which we attribute to the inherent uncertainties of dating bulk material. Charcoal sample SLO18_SK10 from unit U5 dates to 21401987 cal BP. This is slightly younger than SLO18_SK9, which is in line with its stratigraphic position. Thus, sample SKO18_SK8 likely underestimates the age of the unit below the fractured clast. A charcoal sample from U10 right above U5, SLO18_SK11, is about $1.6 \mathrm{kyr}$ younger (492315 cal BP) than U5, which is again in stratigraphic order. However, another sample from the base of unit U10 gives an age of 2307-2056 cal BP (sample SLO18_SK13). This rather old age could be explained by considering that unit U10 consists of washed-in material, which could include older charcoal fragments with a complex history. However, we consider the young age of sample SLO18_SK11 to be an outlier because it is significantly younger than all other samples. From the northern trench wall, we can conservatively deduce that the deformation occurred after the deposition of units U1U6, that is, after 2645 cal BP (U5). 
We obtained three samples from the southern trench wall. Sample SLO18_SK2 is from a charcoal from unit U5 and returned an age of 2067-1924 cal BP. This fits perfectly well with the age of U5 in the northern trench wall. Unfortunately, only bulk organic material could be sampled from the fissure fill. Sample SLO18_SK14 gave an age of 2378-2306 cal BP. This is older than unit U5, which was cut by the fissure. We attribute this discrepancy to the uncertainties related to ${ }^{14} \mathrm{C}$ dating of bulk material. The third sample from the southern trench wall, SLO18_SK6, was a charcoal from unit U10 and returned an age of 2440-2315 cal BP. This is older than unit U5 but similar to the bulk sample from the fissure fill. The most conservative interpretation of the dating results from the southern trench wall is that the deformation occurred before 2306 cal BP, which is the age of the fissure fill material.

All samples with the exception of young charcoal sample SLO18_SK11 cluster in a period between ca. 1.5-2.5 ka. We interpret this cluster as the time span in which most of the sedimentary units were emplaced. The younger age of sample SLO18_SK11 is most likely an outlier.

Taking the results from both trench walls together leads us to conclude that the observed deformation can be bracketed to 2645-2306 cal BP: the oldest depositional age in the affected units is 2645 cal BP from the material of unit U1; the fissure fill is not younger than $2306 \mathrm{cal} \mathrm{BP}$ as indicated by samples SLO18_SK6 and SLO18_SK14. This time span excludes the 1511 Idrija earthquake as the causative event and contradicts the results of Bavec et al. (2013), who trenched the fault close to our site (Figs. 9, 10) and found evidence for deformation dating to about 900-360 cal BP.

\subsection{Implications for regional tectonics and seismic hazard}

Holocene surface-rupturing earthquakes on the NW-SEtrending faults in the area have been proven for the Colle Villano Thrust on the mountain front in Italy (Falcucci et al., 2018), for the Predjama Fault (this study), and for the Idrija Fault (Bavec et al., 2013; this study). Historical earthquakes on the Idrija Fault and in the Ljubljana Basin exceeded $M_{\mathrm{w}} 6.0$ (e.g. Ribarič, 1982; Fitzko et al., 2005; Cecić, 2015). Instrumental earthquakes on the Ravne Fault had magnitudes of $M_{\mathrm{S}} 5.7$ and $M_{\mathrm{w}} 5.2$ (Bajc et al., 2001; Kastelic et al., 2004, 2008; Gosar, 2019a, b). These observations indicate that the crustal deformation due to the northward motion of Adria is not localised and that the long time-averaged seismic moment release is probably more widely distributed than previously estimated from historical and instrumental data (Serpelloni et al., 2016).

A simple thought experiment can be used to estimate an upper bound of the slip rates in the DFS. The GPS velocity of Adria with respect to stable Eurasia is $3 \mathrm{~mm} / \mathrm{a}$ in a northerly direction (Fig. 1; Weber et al., 2010; Metois et al., 2015). If the entire northward motion of Adria were accommodated by the right-lateral motion on the DFS striking $\sim 130^{\circ}$, the

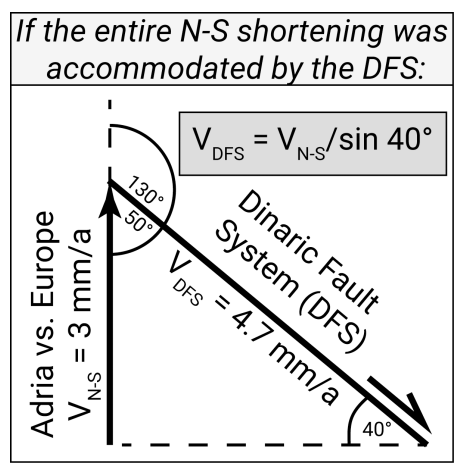

Figure 12. Simple maximum slip rate estimation for the DFS in western Slovenia. A northward velocity of Adria with respect to Europe of $3 \mathrm{~mm} / \mathrm{a}$ (Weber et al., 2010) would lead to $4.7 \mathrm{~mm} / \mathrm{a}$ of right-lateral strike slip on the Dinaric Fault System if this were the only structure to accommodating the deformation. Hence, the combined slip rates of the DFS cannot exceed $4.7 \mathrm{~mm} / \mathrm{a}$. Atanackov et al. (2021) estimate a combined right-lateral slip rate of $\sim 2.5 \mathrm{~mm} / \mathrm{a}$ for the western part of the DFS. The remaining slip must be accommodated further to the east, where another set of shorter right-lateral faults is present (Atanackov et al., 2021), and by the Sava and the Periadriatic faults (Fig. 1).

summed slip rate could not exceed $4.7 \mathrm{~mm} / \mathrm{a}$ (Fig. 12). However, at least $1 \mathrm{~mm} / \mathrm{a}$ of right-lateral slip is accommodated by the Periadriatic Fault system and the Sava Fault, which strike in more easterly directions (Vrabec et al., 2006). Atanackov et al. (2021) estimate that another $1-2 \mathrm{~mm} / \mathrm{a}$ are taken up by shorter right-lateral faults east of the Idrija Fault. Only $\sim 2.5 \mathrm{~mm} / \mathrm{a}$ of right-lateral slip can be accommodated by the DFS. Slip rate estimates for single faults of the DFS vary between $0.05-2.0 \mathrm{~mm} / \mathrm{a}$ according to the available data (Kastelic and Carafa, 2012; Moulin et al., 2016; Atanackov et al., 2021). Given that only $\sim 2.5 \mathrm{~mm} / \mathrm{a}$ are available in total, the higher estimates seem to be less likely, unless in the DFS one fault takes up most of the slip. This is probably not the case. Seismicity does not concentrate on a single fault of the DFS (Fig. 1; Ribarič, 1982; Vičič et al., 2019; Albini et al., 2013). Neither our study nor the paleoseismological investigations by Bavec et al. (2013) and Falcucci et al. (2018) revealed evidence for short earthquake recurrence intervals. At the Predjama Fault, we found structures that could be interpreted as earthquake-related deformation in the past $13 \mathrm{kyr}$. For the Idrija Fault, only one earthquake could be proven for the last $2 \mathrm{kyr}$ (Bavec et al., 2013, this study). Falcucci et al. (2018) document three ruptures on the Colle Villano Thrust. The oldest one pre-dates $7 \mathrm{ka}$, the two younger ones happened probably after the 6th century CE. The Ravne Fault had two events of magnitude $M_{\mathrm{S}} 5.7$ and $M_{\mathrm{w}} 5.2$ in 1998 and 2004, respectively (Bajc et al., 2001; Kastelic et al., 2004, 2008; Gosar, 2019a, b). This shows that all large faults in the DFS are active. Thus, the slip rate for each individual fault of the DFS must be rather low. 
Vičič et al. (2019) reported earthquake swarms on the NW-SE-striking strike-slip faults in Slovenia. On the southern Predjama Fault, more than 3000 earthquakes occurred between late 2009 and early 2011. The strongest event was $M_{\mathrm{L}} 3.5$ and had a predominant strike-slip mechanism. This swarm was accompanied by a transient deformation recorded by an extensometer in Postojna Cave (see Fig. 1 for location). The transient deformation was a few hundreds of a millimetre only. No earthquake swarm occurred near our trench site. However, this raises the question of whether creep or slow-slip events along the NW-SE faults can release a significant part of the seismic moment. In our trench across the Predjama Fault, we found evidence that could indicate rapid deformation, which means that the fault is at least partly, perhaps entirely, locked. Another earthquake swarm on the Idrija Fault NW of our trench site was reported by Vičič et al. (2019), but no swarms occurred at our study site. Vičič et al. (2019) investigated a possible driving mechanism for the swarms and conclude that a slow slip event on the deeper part of the southern Idrija Fault (deeper than $18 \mathrm{~km}$ ) could explain the increased microseismic activity. The shallower part of the Idrija Fault in our study area is locked, as indicated by the structures we found in our trench and by the lack of instrumental seismicity over the period of 1977-2010 reported by Živčić et al. (2011).

From a seismic hazard perspective, it must be assumed that all of the large NW-SE-trending strike-slip faults could host surface-rupturing earthquakes, although recurrence intervals on the individual faults are likely long. Thus, instrumental seismicity and even historical data may not adequately depict the actual hazard.

\section{Conclusions}

With a combination of geomorphological investigations, near-surface geophysical surveys, and paleoseismological trenching we show that surface-rupturing earthquakes happened on the Predjama and Idrija faults in western Slovenia in the Holocene. At least one earthquake on the Predjama Fault resulted in a vertical displacement of $\sim 0.5 \mathrm{~m}$ and an unknown amount of horizontal offset. We can reliably bracket the event to an age of 13-0.7 ka. However, the good agreement of several radiocarbon samples indicates that the deformation more likely happened not earlier than $8.4 \mathrm{ka}$. The Idrija Fault likely had a surface-rupturing earthquake between 2645-2306 cal BP. This earthquake displaced fluvial sediments and caused an open fissure which was then refilled. Since several active faults share the geodesy-derived $3 \mathrm{~mm} / \mathrm{a}$ of relative motion between Adria and Eurasia, none of them can have a high slip rate. These faults are capable of strong earthquakes, which likely dominate the overall seismic moment release on the NW-SE-trending strike-slip faults in the study area. The results of our study show that Holocene surface-rupturing earthquakes occurred on the two faults. No surface ruptures are documented in the instrumental and historical records. Therefore, the earthquakes were likely stronger than those on record. A seismic hazard assessment solely based on instrumental and historical data would miss the strongest possible events.

Data availability. SRTM data are distributed by the Land Processes Distributed Active Archive Center (LPDAAC), located at USGS/EROS, Sioux Falls, SD, http://lpdaac.usgs.gov (LPDAAC, 2013). Slovenian lidar data are provided by Ministry of the Environment and Spatial Planning, Slovenian Environment Agency (ARSO). The two drone DEMs from the trench sites are available at https://www.opentopography.org (last access: 26 March 2021), datasets OTDS.032021.4326.2 (https://doi.org/ 10.5069/G9KW5D75, Grützner, 2021a) and OTDS.032021.4326.1 (https://doi.org/10.5069/G9V9868W, Grützner, 2021b).

Supplement. The supplement related to this article is available online at: https://doi.org/10.5194/se-12-2211-2021-supplement.

Author contributions. CG, KR and KU designed the study. JW and $\mathrm{CG}$ undertook the remote sensing research. CG led the field investigations. SA, NS, JW, BV, PJR, MV, and CG ran the field campaign. SA and NS analysed the geophysics results. CG compiled the data and wrote the initial draft of the paper. All authors reviewed and edited first and final drafts.

Competing interests. The authors declare that they have no conflict of interest.

Disclaimer. Publisher's note: Copernicus Publications remains neutral with regard to jurisdictional claims in published maps and institutional affiliations.

Special issue statement. This article is part of the special issue "New insights into the tectonic evolution of the Alps and the adjacent orogens". It is not associated with a conference.

Acknowledgements. This study was undertaken in the framework of SPP 2017 - Mountain Building Processes in 4D. We thank our field crew Alexander Krämer, Andrea Viscolani, Hamid Sana, and Wahid Abbas for their support. This work benefitted from discussions with Jure Atanackov, Jernej Jež, and Tomaž Fabec, who also provided a 19th-century cadaster plan from the Banjšice site. Elena Makorič (Pokrajinski arhiv v Novi Gorici) is thanked for finding the historical photographs from World War I. We thank the reviewers for their very detailed, thorough, and constructive comments, which helped us to improve our paper. 
Financial support. This research has been supported by the Deutsche Forschungsgemeinschaft (grant nos. GR 4371/1-1 and GR 4371/3-1) and the Javna Agencija za Raziskovalno Dejavnost RS (grant no. P1-0011).

Review statement. This paper was edited by Christian Sue and reviewed by Riccardo Vassallo and Juan M. Insua-Arevalo.

\section{References}

Agosta, F., Ruano, P., Rustichelli, A., Tondi, E., Galindo-Zaldívar, J., and de Galdeano, C. S.: Inner structure and deformation mechanisms of normal faults in conglomerates and carbonate grainstones (Granada Basin, Betic Cordillera, Spain): Inferences on fault permeability, J. Struct. Geol., 45, 4-20, 2012.

Albini, P., Locati, M., Rovida, A., and Stucchi, M.: European Archive of Historical EArthquake Data (AHEAD), Istituto Nazionale di Geofisica e Vulcanologia (INGV) [data set], https://doi.org/10.6092/ingv.it-ahead, 2013.

Alfaro, P., Galindo-Zaldívar, J., Jabaloy, A., López-Garrido, A. C., and de Galdeano, C. S.: Evidence for the activity and paleoseismicity of the Padul fault (Betic Cordillera, southern Spain), Acta geológica hispánica, 36, 283-295, 2001.

Anderson, H. A. and Jackson, J. A.: Active tectonics of the Adriatic region, Geophys. J. R. Astron. Soc., 91, 937-983, https://doi.org/10.1111/j.1365-246X.1987.tb01675.x, 1987.

Aoudia, A., Saraó, A., Bukchin, B., and Suhadolc, P.: The 1976 Friuli (NE Italy) thrust faulting earthquake: a reappraisal 23 years later, Geophys. Res. Lett., 27, 573-576, 2000.

ARSO: Ministry of the Environment and Spatial Planning, Slovenian Environment Agency [data set], available at: https: //gis.arso.gov.si/geoportal/catalog/main/home.page, last access: 15 July 2019.

Atanackov, J., Jamšek Rupnik, P., Jež, J., Celarc, B., Novak, M., Milanič, B., Markelj, A., Bavec, M., and Kastelic, V.: Database of active faults in Slovenia: compiling a new active fault database at the junction between the Alps, the Dinarides and the Pannonian Basin tectonic domains, Front. Earth Sci., 9, 151, https://doi.org/10.3389/feart.2021.604388, 2021.

Atwater, B. F.: Geologic evidence for earthquakes during the past 2000 years along the Copalis River, southern coastal Washington, J. Geophys. Res.-Sol. Ea., 97, 1901-1919, 1992.

Audemard, F. A.: Surface rupture of the Cariaco July 09, 1997 earthquake on the El Pilar fault, northeastern Venezuela, Tectonophysics, 424, 19-39, 2006.

Bajc, J., Aoudia, A., Saraó, A., and Suhadolc, P: The 1998 BovecKrn Mountain (Slovenia) Earthquake Sequence, Geophys. Res. Lett., 28, 1839-1842, 2001.

Barrell, D. J. A., Litchfield, N. J., Townsend, D. B., Quigley, M., Van Dissen, R. J., Cosgrove, R., Cox, S. C., Furlong, K., Villamor, P., Begg, J. G., Hemmings-Sykes, S., Jongens, R., Mackenzie, H., Noble, D., Stahl, T., Bilderback, E., Duffy, B., Henham, H., Klahn, A., Lang, E. M. W., Moody, L., Nicol, R., Pedley, K., and Smith, A.: Strike-slip ground-surface rupture (Greendale Fault) associated with the 4 September 2010 Darfield earthquake, Canterbury, New Zealand, Q. J. Eng. Geol. Hydroge., 44, 283-291, 2011.
Bavec, M., Car, M., Stopar, R., Jamšek, P., and Gosar, A.: Geophysical evidence of recent activity of the Idrija fault, Kanomlja, NW Slovenia, Materials and Geoenvironment, 59, 247-256, 2012.

Bavec, M., Atanackov, J., Celarc, B., Hajdas, I., Jamšek Rupnik, P., Jež, J., Kastelic, V., Milanič, B., Novak, M., Skaberne, G., and Žibret, G.: Evidence of Idrija fault seismogenic activity during the Late Holocene including the 1511 Mm 6.8 earthquake, in: Proceedings of the 4th International INQUA Meeting on Paleoseismology, edited by: Grützner, C., Rudersdorf, A., PérezLópez, R., and Reicherter, K., Active Tectonics and Archeoseismology (PATA), 9-14 October 2013, Aachen, 23-26, ISBN 9783-00-042796-1, 2013.

Bertran, P., Manchuel, K., and Sicilia, D.: Discussion on "Palaeoseismic structures in Quaternary sediments, related to an assumed fault zone north of the Permian Peissen-Gnutz salt structure (NW Germany)-Neotectonic activity and earthquakes from the Saalian to the Holocene" (Grube, 2019), Geomorphology, 365, 106704, https://doi.org/10.1016/j.geomorph.2019.03.010, 2020.

Bigi, G., Cosentino, D., Parotto, M., Sartori, R., and Scandone, P.: Structural model of Italy, 1:500.000, Quaderni de La Ricerca Scientifica, C.N.R., 114, 1990.

Bousquet, R., Schmid, S. M., Zeilinger, G., Oberhänsli, R., Rosenberg, C., Molli, G., Robert, C., Wiederkehr, M., and Rossi, Ph.: Tectonic Framework of the Alps, Map 1:1000 000, CCGM/CGMW (Commission for the Geological Map of the World, Paris), 2012.

Bronk Ramsey, C.: Bayesian analysis of radiocarbon dates, Radiocarbon, 51, 337-360, 2009.

Buser, S.: Geological Map of Slovenia - 1:250.000, Geological Survey of Slovenia, Ljubljana, 2009.

Calais, E., Nocquet, J. M., Jouanne, F., and Tardy, M.: Current strain regime in the Western Alps from continuous Global Positioning System measurements, Geology 30, 651-654, https://doi.org/10.1130/00917613(2002)030<0651:CSRITW>2.0.CO;2, 2002.

Camassi, R., Caracciolo, C. H., Castelli, V., and Slejko, D.: The 1511 Eastern Alps earthquakes: a critical update and comparison of existing macroseismic datasets, J. Seismol., 15, 191-213, 2011.

Čar, J.: Geological structure of the Idrija - Cerkno hills: Explanatory book to the Geological map of the Idrija - Cerkljansko hills between Stopnik and Rovte 1:25000, Geological survey of Slovenija, Ljubljana, 2010.

Čarman, M., Živčić, M. and Ložar Stopar, M.: Earthquakes Near Ilirska Bistrica in 2010. Earthquakes in 2010. ARSO, 2011.

Carulli, G. B.: Carta Geologica del Friuli Venezia Giulia (Scala $1: 150000$, con Note ill.), SELCA, Firenze, Italy, 2006.

Cecić, I.: Idrijski potres 26. marca 1511 - kaj pravzaprav vemo o njem? [The 26 March 1511 earthquake - What do we know about it?], Geografski obzornik, 58, 24-29, 2011 (in Slovenian).

Cecić, I.: Earthquakes in Tuhinj Valley (Slovenia) In 1840, J. Seismol., 19, 469-490, 2015.

Cheloni, D., D'Agostino, N., D’Anastasio, E., and Selvaggi, G.: Reassessment of the source of the 1976 Friuli, NE Italy, earthquake sequence from the joint inversion of high-precision levelling and triangulation data, Geophys. J. Int., 190, 1279-1294, 2012.

Choi, J. H., Klinger, Y., Ferry, M., Ritz, J. F., Kurtz, R., Rizza, M., Bollinger, L., Davaasambuu, B., Tsend-Ayush, N., and Dem- 
berel, S.: Geologic inheritance and earthquake rupture processes: The $1905 M \geq 8$ Tsetserleg-Bulnay strike-slip earthquake sequence, Mongolia, J. Geophys. Res.-Sol. Ea., 123, 1925-1953, 2018.

Copley, A., Grützner, C., Howell, A., Jackson, J., Penney, C., and Wimpenny, S: Unexpected earthquake hazard revealed by Holocene rupture on the Kenchreai Fault (central Greece): Implications for weak sub-fault shear zones, Earth Planet. Sci. Lett., 486, 141-154, 2018.

Cubrinovski, M., Robinson, K., Taylor, M., Hughes, M., and Orense, R.: Lateral spreading and its impacts in urban areas in the 2010-2011 Christchurch earthquakes, New Zeal. J. Geol. Geop., 55, 255-269, 2012.

Cunningham, D., Grebby, S., Tansey, K., Gosar, A., and Kastelic, V.: Application of airborne LiDAR to mapping seismogenic faults in forested mountainous terrain, southeastern Alps, Slovenia, Geophys. Res. Lett., 33, L20308, https://doi.org/10.1029/2006GL027014, 2006.

Cunningham, D., Gosar, A., Kastelic, V., Grebby, S., and Tansey, K.: Multi-disciplinary investigations of active faults in the Julian Alps, Slovenia, Acta Geodyn. Geomater., 4, 77-85, 2007.

D’Agostino, N., Cheloni, D., Mantenuto, S., Selvaggi, G., Michelini, A., and Zuliani, D.: Strain accumulation in the southern Alps (NE Italy) and deformation at the northeastern boundary of Adria observed by CGPS measurements, Geophys. Res. Lett., 32, L19306, https://doi.org/10.1029/2005GL024266, 2005.

D’Agostino, N., Avallone, A., Cheloni, D., D'Anastasio, E., Mantenuto, S., and Selvaggi, G.: Active tectonics of the Adriatic region from GPS and earthquake slip vectors, J. Geophys. Res.-Sol. Ea., 113, B12413, https://doi.org/10.1029/2008JB005860, 2008.

Duman, T. Y., Emre, O., Dogan, A., and Ozalp, S.: Step-over and bend structures along the 1999 Duzce earthquake surface rupture, North Anatolian fault, Turkey, B. Seismol. Soc. Am., 95, 12501262, 2005.

Eidelman, A. and Reches, Z. E.: Fractured pebbles - A new stress indicator, Geology, 20, 307-310, 1992.

England, P. and Jackson, J.: Uncharted seismic risk, Nat. Geosci., 4, 348-349, https://doi.org/10.1038/ngeo1168, 2011.

Falcucci, E., Poli, M. E., Galadini, F., Scardia, G., Paiero, G., and Zanferrari, A.: First evidence of active transpressive surface faulting at the front of the eastern Southern Alps, northeastern Italy: insight on the 1511 earthquake seismotectonics, Solid Earth, 9, 911-922, https://doi.org/10.5194/se-9-911-2018, 2018.

Fitzko, F., Suhadolc, P., Aoudia, A., and Panza, G. F.: Constraints on the location and mechanism of the 1511 Western-Slovenia earthquake from active tectonics and modeling of macroseismic data, Tectonophysics, 404, 77-90, https://doi.org/10.1016/j.tecto.2005.05.003, 2005.

Froitzheim, N., Schmid, S. M., and Frey, M.: Mesozoic paleogeography and the timing of eclogite-facies metamorphism in the Alps: a working hypothesis, Eclogae Geol. Helv., 89, 81-110, 1996.

Glaise von Horstenau, E.: Österreich-Ungarns letzter Krieg 19141918. Vol. 6 - Das Kriegsjahr 1917. Verl. der Militärwiss, Mitteilungen, Vienna, Austria, 1932.

Gosar, A.: Review of geological and seismotectonic investigations related to $1998 \mathrm{Mw} 5.6$ and $2004 \mathrm{Mw} 5.2$ earthquakes in Krn Mountains, Geologija, 62/1, 59-71, 2019a.
Gosar, A.: Review of seismological investigations related to 1998 Mw 5.6 and 2004 Mw5.2 earthquakes in Krn Mountains, Geologija, 62/1, 73-86, 2019b.

Gosar, A.: Measurements of tectonic micro-displacements within the Idrija fault zone in the Učja valley (W Slovenia), Acta Geogr. Slov., 60/1, 79-93, 2020.

Gosar, A., Šebela, S., Košták, B., and Stemberk, J.: On the state of the TM 71 extensometer monitoring in Slovenia: seven years of micro-tectonic displacement measurements, Acta Geodyn. Geomater., 8, 389-402, 2011.

Grünthal, G., Wahlström, R., and Stromeyer, D.: The SHARE European Earthquake Catalogue (SHEEC) for the time period 1900-2006 and its comparison to the European-Mediterranean Earthquake Catalogue (EMEC), J Seismol., 17, 1339-1344, https://doi.org/10.1007/s10950-013-9379-y, 2013.

Grützner, C.: Banjšice trench site, Predjama Fault, Slovenia, OpenTopography [data set], https://doi.org/10.5069/G9KW5D75, $2021 \mathrm{a}$.

Grützner, C.: Srednja Kanomlja trench site, Idrija Fault, Slovenia, OpenTopography [data set] https://doi.org/10.5069/G9V9868W, 2021b.

Grützner, C., Carson, E., Walker, R. T., Rhodes, E. J., Mukambayev, A., Mackenzie, D., Elliott, J. R., Campbell, G., and Abdrakhmatov, K.: Assessing the activity of faults in continental interiors: Palaeoseismic insights from SE Kazakhstan, Earth Planet. Sc. Lett., 459, 93-104, 2017.

Grützner, C., Aschenbrenner, S., Krämer, A., Reicherter, K., Saifelislam, N., Ustaszewski, K., Viscolani, A., and Welte, J.: Geophysical survey (GPR, ERT, magnetic) on active faults in Slovenia and Italy, PANGAEA, https://doi.pangaea.de/10.1594/PANGAEA.922902, 2020.

Handy, M. R., Schmid, S. M., Bousquet, R., Kissling, E., and Bernoulli, D.: Reconciling plate-tectonic reconstructions of Alpine Tethys with the geological-geophysical record of spreading and subduction in the Alps, Earth-Sci. Rev., 102, 121-158, 2010.

Handy, R. M., Ustaszewski, K., and Kissling, E.: Reconstructing the Alps-Carpathians-Dinarides as a key to understanding switches in subduction polarity, slab gaps and surface motion, Int. J. Earth Sci., 104, 1-26, https://doi.org/10.1007/s00531-014-10603, 2015.

Hayes, G. P., Briggs, R. W., Sladen, A., Fielding, E. J., Prentice, C., Hudnut, K., Mann, P., Taylor, F. W., Crone, A. J., Gold, R., and Ito, T.: Complex rupture during the 12 January 2010 Haiti earthquake, Nat. Geosci., 3, 800-805, 2010.

Herak, M., Herak, D., and Markušić, S.: Fault plane solutions for earthquakes (1956-1995) in Croatia and neighboring regions, Geofizika, 12, 43-56, 1995.

Herak, D., Herak, M., and Tomljenović, B.: Seismicity and earthquake focal mechanisms in North-Western Croatia, Tectonophysics, 465, 212-220, 2009.

Herak, D., Sović, I., Cecić, I., Živčić, M., Dasović, I., and Herak, M.: Historical seismicity of the Rijeka region (northwest external Dinarides, Croatia) - Part I: Earthquakes of 1750, 1838, and 1904 in the Bakar epicentral area, Seismol. Res. Lett., 88, 904-915, 2017.

Herak, M., Živčić, M., Sović, I., Cecić, I., Dasović, I., Stipčević, J., and Herak, D.: Historical Seismicity of the Rijeka Region 
(Northwest External Dinarides, Croatia) - Part II: The Klana Earthquakes of 1870, Seismol. Res. Lett., 89, 1524-1536, 2018.

Hooyer, T. S. and Iverson, N. R.: Clast-fabric development in a shearing granular material: implications for subglacial till and fault gouge, Geol. Soc. Am. Bull., 112, 683-692, 2000.

Howarth, J. D., Cochran, U. A., Langridge, R. M., Clark, K., Fitzsimons, S. J., Berryman, K., Villamor, P., and Strong, D. T.: Past large earthquakes on the Alpine Fault: Paleoseismological progress and future directions, New Zeal. J. Geol. Geop., 61, 309-328, 2018

ISRM, Commission on Standardization of Laboratory and Field Test: Suggested Methods for the Rock Characterization, Testing and Monitoring, edited by: Brown, E. T., Pergamon Press, Oxford, UK, 211 pp., 1981.

Jamšek Rupnik, P., Živčić, M., Atanackov, J., Celarc, B., Jež, J., Novak, M., Milanič, B., Jesenko, T., Ložar Stopar, M. and Bavec, M.: Seismotectonic map, in: Geological atlas of Slovenia, edited by: Novak, M. and Rman, N., Geological Survey of Slovenia, Ljubljana, 96-97, 2016.

Kastelic, V. and Carafa, M. M. C.: Fault slip rates for the active external Dinarides thrust-and-fold belt, Tectonics, 31, TC3019, https://doi.org/10.1029/2011TC003022, 2012.

Kastelic, V., Živčić, M., Pahor, J., and Gosar, A.: Seismotectonic characteristics of the 2004 earthquake in Krn mountains, Potresi v letu 2004, ARSO, Ljubljana, 78-87, 2004.

Kastelic, V., Vrabec, M., Cunningham, D., and Gosar, A.: NeoAlpine structural evolution and present-day tectonic activity of the eastern Southern Alps: The case of the Ravne Fault, NW Slovenia, J. Struct. Geol., 30, 963-975, 2008.

Landgraf, A., Kübler, S., Hintersberger, E., and Stein, S.: Active tectonics, earthquakes and palaeoseismicity in slowly deforming continents. Geol. Soc. Lond. Spec. Publ., 432, 1-12, https://doi.org/10.1144/SP432.13, 2017.

Langridge, R. M., Villamor, P., Howarth, J. D., Ries, W. F., Clark, K. J., and Litchfield, N. J.: Reconciling an Early NineteenthCentury Rupture of the Alpine Fault at a Section End, Toaroha River, Westland, New Zealand, B. Seismol. Soc. Am., 111, 514540, https://doi.org/10.1785/0120200116, 2020.

LPDAAC: SRTM data, Land Processes Distributed Active Archive Center [data set], available at: http://lpdaac.usgs.gov (last access: 11 July 2019), 2013.

Little, T. A., Morris, P., Hill, M. P., Kearse, J., Van Dissen, R. J., Manousakis, J., Zekkos, D., and Howell, A.: Coseismic deformation of the ground during large-slip strike-slip ruptures: Finite evolution of "mole tracks", Geosphere, 17, 1170-1192, https://doi.org/10.1130/GES02336.1, 2021.

McNeill, L. C., Collier, R. L., De Martini, P. M., Pantosti, D., and D'Addezio, G.: Recent history of the Eastern Eliki Fault, Gulf of Corinth: geomorphology, palaeoseismology and impact on palaeoenvironments, Geophys. J. Int., 161, 154-166, 2005.

Metois, M., D’Agostino, N., Avallone, A., Chamot-Rooke, N., Rabaute, A., Duni, L., Kuka, N., Koci, R., and Georgiev, I.: Insights on continental collisional processes from GPS data: Dynamics of the peri-Adriatic belts, J. Geophys. Res.-Sol. Ea., 120, 8701-8719, 2015.

Mlakar, I.: Vloga postrudne tektonike pri iskanju novih orudenih con na območju Idrije, Rudarsko-metalurški zbornik (Ljubljana), $1,18-25,1964$.
Mlakar I. and Čar J., Geological map of the Idrija - Cerkljansko hills between Stopnik and Rovte - 1:25,000, Geological Survey of Slovenia, Ljubljana, 2010.

Moulin, A., Benedetti, L., Gosar, A., Jamšek Rupnik, P., Rizza, M., Bourlès, D., and Ritz, J. F.: Determining the present-day kinematics of the Idrija fault (Slovenia) from airborne LiDAR topography, Tectonophysics, 628, 188-205, 2014.

Moulin, A., Benedetti, L., Rizza, M., Jamšek Rupnik, P., Gosar, A., Bourles, D., Keddadouche, K., Aumaître, G., Arnold, M., Guillou, V., and Ritz, J. F.: The Dinaric fault system: Large-scale structure, rates of slip, and PlioPleistocene evolution of the transpressive northeastern boundary of the Adria microplate, Tectonics, 35, 2258-2292, https://doi.org/10.1002/2016TC004188, 2016.

Papathanassiou, G. and Pavlides, S.: Using the INQUA scale for the assessment of intensity: Case study of the 2003 Lefkada (Ionian Islands), Greece earthquake, Quaternary Int., 173, 4-14, 2007.

Patyniak, M., Landgraf, A., Dzhumabaeva, A., Abdrakhmatov, K. E., Rosenwinkel, S., Korup, O., Preusser, F., Fohlmeister, J., Arrowsmith, J. R., and Strecker, M. R.: Paleoseismic Record of Three Holocene Earthquakes Rupturing the Issyk-Ata Fault near Bishkek, North Kyrgyzstan, B. Seismol. Soc. Am., 107, 27212737, 2017.

Peruzza, L., Poli, M. E., Rebez, A., Renner, G., Rogledi, S., Slejko, D., and Zanferrari, A.: The 1976-1977 seismic sequence in Friuli: new seismotectonic aspects, Mem. Soc. Geol. It., 57, 391400, 2002.

Petersen, G. M., Cesca, S., Heimann, S., Niemz, P., Dahm, T., Kühn, D., Kummerow, J., Plenefisch, T., and the AlpArray and AlpArray-Swath-D working groups: Regional centroid moment tensor inversion of small to moderate earthquakes in the Alps using the dense AlpArray seismic network: challenges and seismotectonic insights, Solid Earth, 12, 1233-1257, https://doi.org/10.5194/se-12-1233-2021, 2021.

Placer, L.: Structural history of the Idrija mercury deposit, Geologija, 25/1, 7-94, 1982.

Placer, L., Vrabec, M., and Celarc, B.: The bases for understanding of the NW Dinarides and Istria Peninsula tectonics, Geologija, 53, 55-86, https://doi.org/10.5474/geologija.2010.005, 2010.

Poljak, M., Živčić, M., and Zupančič, P.: The seismotectonic characteristics of Slovenia, Pure Appl. Geophys., 157, 37-55, 2000.

Pondrelli, S., Morelli, A., Ekström, G., Mazza, S., Boschi, E., and Dziewonski, A. M.: European-Mediterranean regional centroidmoment tensors: 1997-2000, Phys. Earth Planet. Int., 130, 71101, https://doi.org/10.1016/S0031-9201(01)00312-0, 2002.

Pondrelli, S., Salimbeni, S., Morelli, A., Ekström, G., Postpischl, L., Vannucci, G., and Boschi, E.: European-Mediterranean regional centroid moment tensor catalog: solutions for 2005-2008, Phys. Earth Planet. Int., 185, 74-81, 2011.

Radjai, F., Wolf, D. E., Jean, M., and Moreau, J. J.: Bimodal character of stress transmission in granular packings, Phys. Rev. Lett., 80, 61-64, https://doi.org/10.1103/PhysRevLett.80.61, 1998.

Ramsay, D. M.: Deformation of pebbles in lower Old Red Sandstone conglomerates adjacent to the Highland Boundary fault, Geol. Mag., 101, 228-248, 1964.

Reimer, P. J., Bard, E., Bayliss, A., Beck, J. W., Blackwell, P. G., Bronk Ramsey, C., Buck, C. E., Cheng, H., Edwards, R. L., Friedrich, M., Grootes, P. M., Guilderson, T. P., Hafl-idason, H., Hajdas, I., Hatté, C., Heaton, T. J., Hoffmann, D. L., Hogg, A. G., 
Hughen, K. A., Kaiser, K. F., Kromer, B., Manning, S. W., Niu, M., Reimer, R. W., Richards, D. A., Scott, E. M., Southon, J. R., Staff, R. A., Turney, C. S. M., and van der Plicht, J.: IntCal13 and Marine13 radiocarbon age calibration curves 0-50,000 years cal BP, Radiocarbon, 55, 1869-1887, 2013.

Ribarič, V.: The Idrija earthquake of March 26, 1511 - a reconstruction of some seismological parameters, Tectonophysics, 53, 315-324, 1979.

Ribarič, V.: Seismicity of Slovenia-Catalogue of Earthquakes (792 A.D-I98I), SZ SRS, Publication, Ser. A, No. I-I, Ljubljana, 650 pp., 1982.

Sapkota, S. N., Bollinger, L., Klinger, Y., Tapponnier, P., Gaudemer, Y., and Tiwari, D.: Primary surface ruptures of the great Himalayan earthquakes in 1934 and 1255, Nat. Geosci., 6, 71-76, 2013

Schmid, S. M., Fügenschuh, B., Kissling, E., and Schuster, R.: Tectonic Map and overall architecture of the Alpine orogen, Eclogae Geol. Helv., 97, 93-117, 2004.

Schmid, S. M., Bernoulli, D., Fügenschuh, B., Matenco, L., Schefer, S., Schuster, R., Tischler, M., and Ustaszewski, K.: The Alpine-Carpathian-Dinaridic orogenic system: correlation and evolution of tectonic units, Swiss J. Geosci., 101, 139-183, https://doi.org/10.1007/s00015-008-1247-3, 2008.

Serpelloni, E., Vannucci, G., Anderlini, L., and Bennett, R. A.: Kinematics, seismotectonics and seismic potential of the eastern sector of the European Alps from GPS and seismic deformation data, Tectonophysics, 688, 157-181, 2016.

Silva, P. G., Reicherter, K., Grützner, C., Bardají, T., Lario, J., Goy, J. L., Zazo, C., and Becker-Heidmann, P.: Surface and subsurface palaeoseismic records at the ancient Roman city of Baelo Claudia and the Bolonia Bay area, Cádiz (south Spain), Geol. Soc. Lond. Spec. Publ., 316, 93-121, 2009.

Slejko, D., Carulli, G. B., Nicolich, R., Rebez, A., Zanferrari, A., Cavallin, A., Doglioni, C., Carraro, F., Castaldini, D., Iliceto, V., Semenza, E., and Zanolla, C.: Seismotectonics of the Eastern Southern Alps: a review, Boletino di Geofisica Teorica ed Applicata, 31, 109-136, 1989.

Stein, S., Liu, M., Calais, E., and Li, Q.: Mid-continent earthquakes as a complex system, Seismol. Res. Lett., 80, 551-553, https://doi.org/10.1785/gssrl.80.4.551, 2009.

Stucchi, M., Rovida, A., Capera, A. G., Alexandre, P., Camelbeeck, T., Demircioglu, M. B., Gasperini, P., Kouskouna, V., Musson, R. M. W., Radulian, M., Sesetyan, K., Vilanova, S., Baumont, D., Bungum, H., Fäh, D., Lenhardt, W., Makropoulos, K., Martinez Solares, J. M., Scotti, O., Živčić, M., Albini, P., Batllo, J., Papaioannou, C., Tatevossian, R., Locati, M., Meletti, C., Viganò, D., and Giardini, D.: The SHARE European earthquake catalogue (SHEEC) 1000-1899, J. Seismol., 17, 523-544, https://doi.org/10.1007/s10950-012-9335-2, 2013.

Šušteršič, F.: Poljes and caves of Notranjska, Acta Carsologica, 25, 251-289, 1996.

Sylvester, A. G.: Strike-slip faults, Geol. Soc. Am. Bull., 100, 16661703, 1988.

Talebian, M., Fielding, E. J., Funning, G. J., Ghorashi, M., Jackson, J., Nazari, H., Parsons, B., Priestley, K., Rosen, P. A., Walker, R., and Wright, T. J.: The 2003 Bam (Iran) earthquake: Rupture of a blind strike-slip fault, Geophys. Res. Lett., 31, L11611, https://doi.org/10.1029/2004GL020058, 2004.
Thakur, V. C. and Pandey, A. K.: Late Quaternary tectonic evolution of Dun in fault bend/propagated fold system, Garhwal SubHimalaya, Curr. Sci., 87, 1567-1576, 2004.

Tiberi, L., Costa, G., Jamšek Rupnik, P., Cecić, I., and Suhadolc, P.: The 1895 Ljubljana earthquake: can the intensity data points discriminate which one of the nearby faults was the causative one?, J. Seismol., 22, 927-941, https://doi.org/10.1007/s10950018-9743-z, 2018.

Tokarski, A. K. and Strzelecki, P. J.: Fractured clasts in the Mt Currie Conglomerate at Kata Tjuta (Central Australia): evidence of Early Cambrian earthquakes?, Geol. Geophys. Environ., 46, 29, https://doi.org/10.7494/geol.2020.46.1.29, 2020.

Tokarski, A. K., Świerczewska, A., Lasocki, S., Cuong, N. Q., Strzelecki, P. J., Olszak, J., Kukulak, J., Alexanderson, H., Zasadni, J., Krąpiec, M., and Mikołajczak, M.: Active faulting and seismic hazard in the Outer Western Carpathians (Polish Galicia): Evidence from fractured Quaternary gravels, J. Struct. Geol., 141, 104210, https://doi.org/10.1016/j.jsg.2020.104210, 2020.

Treiman, J. A., Kendrick, K. J., Bryant, W. A., Rockwell, T. K., and McGill, S. F.: Primary surface rupture associated with the Mw 7.1 16 October 1999 Hector Mine earthquake, San Bernardino County, California, B. Seismol. Soc. Am., 92, 11711191, 2002.

Ustaszewski, K., Kounov, A., Schmid, S.M., Schaltegger, U., Krenn, E., Frank, W., and Fügeschuh, B.: Evolution of the Adria-Europe plate boundary in the northern Dinarides: From continent-continent collision to backarc extension. Tectonics, 29, 1-34. https://doi.org/10.1029/2010TC002668, 2010.

Valjavec, M. B., Zorn, M., and Ribeiro, D.: Mapping war geoheritage: Recognising geomorphological traces of war, Open Geosci., 10, 385-394, 2018.

Vanneste, K. and Verbeeck, K.: Paleoseismological analysis of the Rurrand fault near Julich, Roer Valley graben, Germany: Coseismic or aseismic faulting history?, Geol. Mijnbouw, 80, 155-170, 2001.

Vičič, B., Aoudia, A., Javed, F., Foroutan, M., and Costa, G.: Geometry and mechanics of the active fault system in western Slovenia, Geophys. J. Int., 217, 1755-1766, 2019.

Vrabec, M.: Evidence of Quaternary faulting in the Idrija fault zone, Učja canyon, NW Slovenia, RMZ - Materials and Geoenvironment, 59, 285-298, 2012.

Vrabec, M. and Fodor, L.: Late Cenozoic tectonics of Slovenia: structural styles at the Northeastern corner of the Adriatic microplate, in: The Adria microplate: GNSS geodesy, tectonics and hazards (NATO Science Series IV, Earth and Environmental Sciences 61), edited by: Pinter, N., Grenerczy, N., Weber, J., Stein, S., and Medak, D., Springer, Dordrecht, 151-168, 2006.

Vrabec, M., Preseren, P. P., and Stopar, B.: GPS study (19962002) of active deformation along the Periadriatic fault system in northeastern Slovenia: tectonic model, Geologica CarpathicaBratislava, 57, 57-65, 2006.

Wang, Y., Amundson, R., and Trumbore, S.: Radiocarbon dating of soil organic matter, Quaternary Res., 45, 282-288, 1996.

Weber, J., Vrabec, M., Pavlovčič-Prešeren, P., Dixon, T., Jiang, Y., and Stopar, B.: GPS-derived motion of the Adriatic microplate from Istria Peninsula and Po Plain sites, and geodynamic implications, Tectonophysics, 483, 214-222, https://doi.org/10.1016/j.tecto.2009.09.001, 2010. 
Zabcı, C., Akyüz, H. S., and Sançar, T.: Palaeoseismic history of the eastern part of the North Anatolian Fault (Erzincan, Turkey): Implications for the seismicity of the Yedisu seismic gap, J. Seismol., 21, 1407-1425, 2017.

Zachariasen, J., Berryman, K., Langridge, R., Prentice, C., Rymer, M., Stirling, M., and Villamor, P.: Timing of late Holocene surface rupture of the Wairau fault, Marlborough, New Zealand, New Zeal. J. Geol. Geop., 49, 159-174, 2006.

Žibret, L. and Vrabec, M.: Paleostress and kinematic evolution of the orogen-parallel NW-SE striking faults in the NW External Dinarides of Slovenia unravelled by mesoscale fault-slip data analysis, Geol. Croat., 69, 295-305, 2016.
Živčić, M., Čarman, M., Gosar, A., Jesenko, T., and Zupančič, P.: Potresi ob idrijskem prelomu, in: Anno domini 1511 (Idrijski razgledi, 2011, 1), edited by: Janež, J., Idrija, Mestni muzej., 119126, 2011 (in Slovenian). 